\title{
Development of fauna of water beetles (Coleoptera) in waters bodies of a river valley - habitat factors, landscape and geomorphology
}

\author{
Joanna Pakulnicka $^{1, *}$, Paweł Buczyński ${ }^{2}$, Piotr Dąbkowski ${ }^{3}$, Edyta Buczyńska $^{4}$, Edyta Stępieñ ${ }^{5}$, \\ Agnieszka Szlauer-Łukaszewska ${ }^{3}$ and Andrzej Zawal ${ }^{3}$ \\ ${ }^{1}$ Department of Ecology and Environmental Protection, University of Warmia and Mazury, Łódzki Square 3, 10-727 Olsztyn, Poland \\ ${ }^{2}$ Department of Zoology, Maria Curie-Skłodowska University, Akademicka 19, 20-033 Lublin, Poland \\ ${ }^{3}$ Department of Invertebrate Zoology and Limnology, Institute for Research on Biodiversity, Faculty of Biology, University of Szczecin, \\ Wąska 13, 71-415 Szczecin, Poland \\ ${ }^{4}$ Department of Zoology, Animal Ecology and Wildlife Management,University of Life Sciences, Akademicka Str. 13, 20-033 Lublin, Poland \\ 5 Department of Plant Taxonomy and Phytogeography, Institute for Research on Biodiversity, Faculty of Biology, University of Szczecin, \\ Wąska Str. 13, 71-415 Szczecin, Poland
}

\begin{abstract}
The goal of the study was to identify the beetle fauna of a small lowland river valley against its spatial arrangement and the directions of beetle migrations between habitats, as well as to determine which environmental factors affect the characteristics of water beetle populations in a river valley's lentic water bodies. The field studies were carried out in various types of water bodies. 112 species of beetles with various ecological characteristics were identified. It was demonstrated that the diversity of water bodies in the valley is conducive to high local species richness. At the same time, the observed high degree of faunistic individualism may be regarded as a sign of poor symmetry in the directions of fauna propagation, particularly that of stagnobionts. The authors argue that high individualism is the consequence of poor hydrological contact between the water bodies due to topography and rare instances of high tide in the river, which, in turn, is the reason for active overflights remaining the main mean of migration between those water bodies. The factors restricting migration of fauna between the water bodies include certain landscape characteristics of the catchment which form topographical obstacles, mainly numerous and dense forest areas. The character of fauna in the respective types of water bodies is affected also by internal environmental factors, particularly the degree to which they are overgrown with macrophytes, type of bottom, type of mineral and organic matter as well as physical parameters of water, such as saturation, $\mathrm{pH}$, temperature and biological oxygen demand.
\end{abstract}

Keywords: water beetles / river valley / migrations / hydrological system / ecological groups / landscape characteristics / environmental factors

\begin{abstract}
Résumé - Développement de la faune de coléoptères aquatiques (Coleoptera) dans les eaux d'une vallée - facteurs de l'habitat, paysage et géomorphologie. Le but de l'étude était d'identifier la faune de coléoptères d'une petite vallée d'une rivière de plaine en fonction de son paysage et des directions des migrations des coléoptères entre les habitats, ainsi que pour déterminer quels facteurs environnementaux influent sur les caractéristiques des populations de coléoptères aquatiques dans les plans d'eau d'une vallée. Les études sur le terrain ont été effectuées dans divers types de masses d'eau. 112 espèces de coléoptères avec diverses caractéristiques écologiques ont été identifiées. Il a été démontré que la diversité des masses d'eau dans la vallée est propice à la haute richesse des espèces locales. Dans le même temps, le degré élevé observé de l'hétérogénéité faunistique peut être considéré comme un signe de mauvaise symétrie dans les directions de propagation de la faune, en particulier celle des stagnobiontes. Les auteurs soutiennent que la forte hétérogénéité est la conséquence d'un mauvais contact hydrologique entre les masses d'eau en raison de la topographie et de rares inondations de la rivière, ce qui, à son tour, est la raison pour laquelle les survols
\end{abstract}

\footnotetext{
* Corresponding author: joanna.pakulnicka@uwm.edu.pl
} 
actifs restent le principal moyen de migration entre ces masses d'eau. Les facteurs limitant la migration de la faune entre les masses d'eau comprennent certaines caractéristiques du paysage du bassin versant qui forment de nombreux obstacles topographiques et les zones forestières denses. Le caractère de la faune dans les différentes masses d'eau est affecté aussi par des facteurs environnementaux internes, en particulier le degré auquel elles sont envahies par les macrophytes, le type de fond, le type de matières minérales et organiques ainsi que des paramètres physiques de l'eau, tels que l'oxygénation, le pH, la température et la DBO5.

Mots-clés : coléoptère aquatique / vallée / migration / système hydrologique / groupe écologique / paysage / facteurs environnementaux

\section{Introduction}

In recent decades, hydrobiologists have been focusing mainly on the subject of large lowland river valleys, especially those that managed to retain their natural character. The various kinds of water bodies found on the floodplain of the river, especially the oxbows that were once the riverbed, along with the river itself, constitute a single, cohesive water system (Biesiadka, 1974; Ward et al., 1999; Robinson et al., 2002). This hydrologically cohesive system of varied water bodies is best considered an integral network of mutual faunistic relations between organisms present in aquatic environments of a river valley (Stanford et al., 1996; Stanley et al., 1997; Robinson et al., 2002; Biesiadka and Pakulnicka, 2004a). That is why scientists have been showing a growing interest in relations between river-dwelling fauna and the fauna of other water bodies within the floodplains of rivers (Castella et al., 1984; Stanford et al., 1996; Van den Brink et al., 1996; Stanley et al., 1997; Ward et al., 1999; Robinson et al., 2002; Biesiadka and Pakulnicka, 2004a). Papers describing the faunistic and ecological features of hydrobiont groups are now available, and point to these being shaped by the system's lasting hydrological interconnection (Kajak, 1959; Castella et al., 1984, 1991; Castella and Amoros, 1988; Ward et al., 2002; Biesiadka and Kurzątkowska, 2003; Biesiadka et al., 2004; Biesiadka et al., 2004; Czachorowski, 2004; Jurkiewicz-Karnkowska, 2006; Reckendorfer et al., 2006; Obolewski et al., 2009; Stryjecki and Kowalczyk-Pecka, 2013; Zawal and Kowalik, 2013; Kowalik et al., 2014; Zawal et al., 2016d).

The literature concerning the beetle fauna inhabiting various aquatic environments is very rich and covers both standing and flowing waters. There is also a number of studies of riverine valley beetle fauna but these most often relate to rivers only (e.g. Biesiadka and Pakulnicka, 2004b; Moroz et al., 2004). There is a deficit of detailed studies presenting a more in-depth analysis of dependencies between the beetle fauna of various waters related hydrologically, particularly between the fauna of rivers and valley water bodies (Biesiadka and Pakulnicka, 2004a; Pakulnicka and Nowakowski, 2012). While the little research that is currently available is certainly not enough, studies conducted so far have confirmed strong relations between the coleopterofauna of rivers and the various water bodies present on the floodplain, especially oxbows (Czachorowski et al., 1993; Mielewczyk, 2003; Biesiadka and Pakulnicka, 2004a; Przewoźny et al., 2006; Persson Vinnersten et al., 2009; Pakulnicka and Nowakowski, 2012; Costea et al., 2013). Similar data can be found also in relation to other water organisms, e.g. dragonflies, aquatic Heteroptera, Trichoptera and Hydrachnidiae (Czachorowski et al., 1993; Biesiadka and Kurzątkowska, 2003; Biesiadka et al., 2004;
Czachorowski, 2004; Buczyński, 2007). The vast diversity of the hydrographic network that makes up an entire mosaic of various habitats obviously promotes species exchange, which, in turn, contributes to a more diverse and richer fauna (Stanley et al., 1997; Wissinger, 1999; Junk, 2000; Tockner et al., 2000; Robinson et al., 2002).

The question that comes to mind - what are the factors affecting the formation of groups of fauna in river valleys - has been raised not only by hydroentomologists, but also researchers of other groups of organisms (Kajak, 1959; Castella et al., 1984, 1991; Castella and Amoros, 1988; Ward, 1998; Ward et al., 2002; Jurkiewicz-Karnkowska, 2006; Reckendorfer et al., 2006; Obolewski et al., 2009).

Biesiadka and Pakulnicka (2004a) point out that for water beetles, which are usually perfect fliers and are characterized with high biological dispersal (Bilton, 1994; Lundkvist et al., 2002), faunistic integration between the river and the water bodies located on the floodplain is influenced by two mechanisms: active overflights and migration of beetles in the floodplain area in time of spate. Despite this, water environments comprising the cohesive hydrological system may still be distinguished by a certain degree of individualism (Marchese and Ezcurra de Drago, 1992; Pakulnicka and Nowakowski, 2012; Costea et al., 2013; Biesiadka and Pakulnicka, 2004a). These individual features are the result of internal environmental (site) factors, such as type of water body, type of substrate, extent of vegetation, area, age, permanence and water flow speed (Castella et al., 1991; Marchese and Ezcurra de Drago, 1992; Winfield Fairchild et al., 2000; Lundkvist et al., 2001; Oertli et al., 2002; Pakulnicka, 2008; Pakulnicka and Nowakowski, 2012; Pakulnicka et al., 2015a,b).

In recent decades, scientists have gained a better understanding of just how important landscape factors are to water environments and the groups of macroinvertebrates inhabiting them; those factors including geomorphology, landscape structure and landscape utilization (Castella et al., 1991; Delettre et al., 1992; Richards and Host, 1994; Richards et al., 1996; Delettre and Morvan, 2000; Galic et al., 2013; Zawal et al., 2016b,c). Not any less important are human activities performed on the river itself, a clear example of which can be seen in the studied River Krapiel (SzlauerŁukaszewska and Zawal, 2014; Bańkowska et al., 2015; Dąbkowski et al., 2016; Stępień et al., 2015; Zawal et al., 2015; 2016d; Płaska et al., 2016). A proper assessment of those influences, as opposed to internal site factors, is, however, still lacking and requires further research.

The aims of this paper have been set to: (1) identify the mechanisms behind the formation of water beetle fauna in the spatial arrangement of a river valley - most importantly to determine the quantitative and qualitative structure of fauna in 
respective types of water environments; (2) assess the direction and strength of beetle migration between water bodies as well as their significance in the forming of a cohesive faunistic system in a river valley; and (3) attempt to address the question of what factors - whether environmental and affecting the water body locally, or perhaps the broader landscape parameters of the catchment - play the greatest part in determining the nature of water beetle groups inhabiting the standing waters in river valleys.

\section{Methods}

Field studies on the fauna of water beetles inhabiting river valleys were conducted on bodies of standing water located in the valley of a small lowland river, the Krapiel (North-West Poland). The river is 70-km long and features a narrow, steep valley. A characteristic feature of the river can be seen in its very rare swelling, with high waters rarely reaching all of the valley's water bodies. In fact, there has been no swelling observed recently. The valley is embedded in a typical agricultural landscape, with a noticeable prevalence of largescale arable land plots and hay meadows. Sylvan ecosystems constitute only a minor part of the area. The faunistic studies were conducted from April to October 2010. 89 research sites were selected across various types of water bodies: springs, small permanent bodies of water, flooded alder swamp forests, bog sedges, oxbows and river marshes, accounting for all possible kinds of water beetle habitats. A description of the research sites can be found in Table 1 . The selected study sites were categorized into 13 macrohabitats (K1-K14, Fig. 1).

For each macrohabitat, samples of fauna were collected from several mesohabitats. The number of mesohabitats that were subsequently taken into account depended on the site's spatial diversity, and was as follows: 2 mesohabitats (at study sites K4, K9-10, K13), 3 (K2-3, K12), 4 (K1, K6, K8, K11, K14) and 5 mesohabitats at study site K7. Each time, all of the mesohabitats had three subsamples collected for the purpose of variability analyses - except for periods of absence of water. Each sampling consisted of 10 energetic sweeps and covered an area of ca. $0.5 \mathrm{~m}^{2}$. Ecotone samples, collected from the water/land boundary area, were also considered. In total, 387 samples were collected from 27 sites situated solely in stagnant waters.

The following water parameters were researched: temperature, $\mathrm{pH}$, electrolytic conductivity and dissolved oxygen content were measured with an Elmetron CX-401 multiparametric sampling probe; water flow using a SonTek acoustic FlowTracker flowmeter; biological oxygen demand $\left(\mathrm{BOD}_{5}\right)$ was measured by Winkler's method, and the remaining parameters using a Slandi LF205 photometer. Three measurements were performed every time and the median was used for further analyses.

At the same time a suitable analysis of the valley's landscape was performed, based on 13 buffer zones and subcatchments defined for each macrohabitat (K1-K14), for which different landscape parameters were described. The buffer zone was described as a $500 \mathrm{~m}$-radius circle around the study site. The catchment of the given study site was defined as a catchment limited by two subsequent macrohabitats. The analysis of the spatial structure of the buffer zones and catchments was based on a set of landscape metrics calculated with the help of TNTmips software by the company MicroImages. Classification was done on the basis of Landsat TM7 28-05-2003 data; edges and linear elements based on a 1:10,000 scale map; classes according to CORINE classification - in case of meadows, simplified classes were applied (merged meadows and pastures due to the minimal share of pastures in the studied area; repeated isoclass using the class merging option in accordance with the dendrogram; completed with drawing vectors to mark class edges). Rivers, roads and drainage trenches are marked as polygons - the patches being of an area of at least $200 \mathrm{~m}$. GPS was applied to determine the coordinates of sampling sites, with the site area defined by a $500 \mathrm{~m}$ radius. The following measures and indicators were used in analyzing landscape structure: (1) Patch square measure - area; (2) Patch density and size measure - number of patches (NUMP), mean patch size (MPS), median of patch sizes (MEDPS), patch size standard deviation (PSSD), patch density (PD); (3) Edge measure total edge length, edge density, mean edge length; (4) Shape measure - mean shape index (MSI), mean patch fractal dimension, sum of patch shape indices; (5) Diversity and distribution indices - mean distance from nearest neighbor, interspersion and juxtaposition index), Shannon's patch diversity index, spatial evenness and patch number index (SEI), catchment area from springs, distance of river from each patch (forests, fields, marshes, facilities, meadows, shrubs, wasteland and water). Upon an analysis of the obtained data, only those landscape parameters were selected that proved to be statistically significant in terms of fauna distribution $(p<0.05)$.

For the sake of proper analysis of beetle fauna, a slightly modified division into ecological groups was applied as proposed by Pakulnicka and Nowakowski (2012). Identified species were classified into five groups: crenophiles, rheophiles, rheobionts, stagnobionts "a" and stagnobionts " $b$ ". Crenophiles are species that are most characteristic of springs, usually preferring cold waters. Rheobionts are species found exclusively in flowing waters which dwell in habitats with a strong river current on a rocky or gravelly substratum. Those species have a low migration capacity and they are the characteristic of flowing waters. Rheophiles are typical of the overgrown zones of sluggish rivers and large, slightly eutrophicated lakes. This group of species is characterized by a high migration capacity which explains their presence in other types of waters of "good ecological status". Type "a" stagnobionts comprise species which are found mostly in small, slightly eutrophicated water bodies. They are characteristic of dystrophic waters (polyhumic - highly mineralized waters with a sand/clay bottom), as well as oxbow lakes with clean water, which are periodically and regularly flushed by flowing waters. Type "b" stagnobionts include species typical of small, strongly eutrophicated water bodies, including intermittent waters. They are generally characterized by a high migration capacity, and they affect the formation of Coleopteran fauna in other types of water bodies (Pakulnicka and Nowakowski, 2012).

The domination index was used in analyzing the groups of beetles inhabiting the researched types of water environments. Similarities between the selected subcatchments were calculated using catchment characteristics based on applying the 
Table 1. Characteristics of the macro- and mesohabitats along the valley of the River Krapiel. Mch - macrohabitats (numbering like in the Fig. 1); Msh - mesohabitats (ac - alder carr, ox - oxbow, pp - permanent pond, rp - riparian pool, se - sedges, sp - spring); Bot - bottom (min - mineral, lea - leaves, org - organic); Dep - depth [m]; pla - plants; Sob - structure of border (for - forest, mea - meadow, tre treas); Dfr - distance from the river [m]; Per - permanence [months].

\begin{tabular}{|c|c|c|c|c|c|c|c|}
\hline Mch & Msh & Bot & Dep & Pla & Sob & Dfr & Per \\
\hline $\mathrm{K} 1$ & $\mathrm{rp}$ & $\min$ & 0.5 & 5 & mea & 5 & 4 \\
\hline $\mathrm{K} 1$ & $\mathrm{rp}$ & $\min$ & 0.1 & 5 & mea & 5 & 4 \\
\hline $\mathrm{K} 1$ & $\mathrm{pp}$ & org, lea & 1 & 0 & tre & 10 & 7 \\
\hline $\mathrm{K} 1$ & $\mathrm{pp}$ & org, lea & 0.1 & 0 & tre & 10 & 7 \\
\hline $\mathrm{K} 1$ & se & $\min$, org & 0.2 & 5 & mea & 10 & 7 \\
\hline $\mathrm{K} 2$ & $\mathrm{pp}$ & $\min$ & 0.2 & 3 & for & 5 & 2 \\
\hline $\mathrm{K} 2$ & $\mathrm{pp}$ & $\min$ & 0.1 & 1 & for & 5 & 2 \\
\hline $\mathrm{K} 2$ & $\mathrm{pp}$ & min, org, lea & 0.2 & 0 & for & 5 & 2 \\
\hline $\mathrm{K} 2$ & $\mathrm{pp}$ & $\min$, org, lea & 0.1 & 0 & for & 5 & 2 \\
\hline K3 & $\mathrm{sp}$ & $\min$, org & 0.1 & 5 & mea & 5 & 2 \\
\hline K3 & $\mathrm{sp}$ & $\min$, org, lea & 0.1 & 3 & tre & 5 & 2 \\
\hline K4 & se & $\min$, org & 0.2 & 5 & mea & 15 & 3 \\
\hline K4 & $\mathrm{ac}$ & org, lea & 0.4 & 1 & for & 20 & 7 \\
\hline K4 & ac & org, lea & 0.1 & 1 & for & 20 & 7 \\
\hline K4 & $\mathrm{pp}$ & org & 0.5 & 0 & tre & 20 & 3 \\
\hline K4 & $\mathrm{pp}$ & org & 0.1 & 0 & tre & 20 & 3 \\
\hline K6 & ox & $\min$, lea & 1 & 0 & for & 40 & 7 \\
\hline K6 & ox & $\min$, lea & 0.1 & 0 & for & 40 & 7 \\
\hline K6 & $\mathrm{ac}$ & org, lea & 0.2 & 0 & for & 10 & 2 \\
\hline K6 & $\mathrm{ac}$ & org, lea & 0.1 & 0 & for & 10 & 2 \\
\hline K7 & $\mathrm{pp}$ & $\min$, lea & 0.1 & 0 & for & 15 & 2 \\
\hline K7 & ox & $\min$, org, lea & 0.2 & 0 & for & 10 & 2 \\
\hline K8 & $\mathrm{rp}$ & org & 0.5 & 4 & mea & 5 & 7 \\
\hline K8 & $\mathrm{rp}$ & org & 0.1 & 5 & mea & 5 & 7 \\
\hline K9 & se & org & 0.2 & 5 & mea & 10 & 2 \\
\hline K9 & $\mathrm{ac}$ & $\min$, org, lea & 0.4 & 0 & for & 20 & 3 \\
\hline K9 & ac & $\min$, org, lea & 0.1 & 0 & for & 20 & 3 \\
\hline K10 & ox & org & 0.7 & 3 & mea & 3 & 7 \\
\hline K10 & ox & org & 0.1 & 5 & mea & 3 & 7 \\
\hline K11 & $\mathrm{rp}$ & org & 0.1 & 0 & for & 2 & 1 \\
\hline K12 & ox & org, lea & 0.4 & 1 & tre & 10 & 7 \\
\hline K12 & ox & org, lea & 0.1 & 0 & tre & 10 & 7 \\
\hline K12 & $\mathrm{sp}$ & org, lea & 0.1 & 1 & for & 10 & 7 \\
\hline K13 & se & $\min$ & 0.4 & 4 & for & 5 & 2 \\
\hline K14 & ox & $\min$ & 0.7 & 0 & tre & 10 & 2 \\
\hline K14 & ox & $\min$ & 0.1 & 0 & tre & 10 & 2 \\
\hline K14 & ox & $\min$ & 0.4 & 0 & mea & 15 & 2 \\
\hline K14 & ox & $\min$ & 0.1 & 0 & mea & 15 & 2 \\
\hline
\end{tabular}

Euclidean Similarity Index, while the actual analyses of faunistic similarities between the studied sites and distinguished subcatchments were defined on basis of Bray-Curtis' quantitative formula (Bray and Curtis, 1957), using the Simple Average Link for hierarchical clustering of objects. The obtained results were presented in a similarity dendrogram. Similarities between objects were determined using Biodiversity Pro v.2 software (McAleece et al., 1997). The objects' (sites') membership to clusters distinguished due to the quantitative structure of the groups of beetles, as well as the clustering of object features distinguished due to structure, were verified using the sign test and McNemara's test (Sokal and Sneath, 1995). All calculations were performed in Statistica 12.0 software.

Relations between the presence of beetle species and the selected environmental parameters of the River Krapiel valley's water bodies were determined using the Canonical Correspondence Analysis direct ordination method (having first performed DCA) (ter Braak, 1986; ter Braak and Verdonschot, 1995). Only features that demonstrated no 


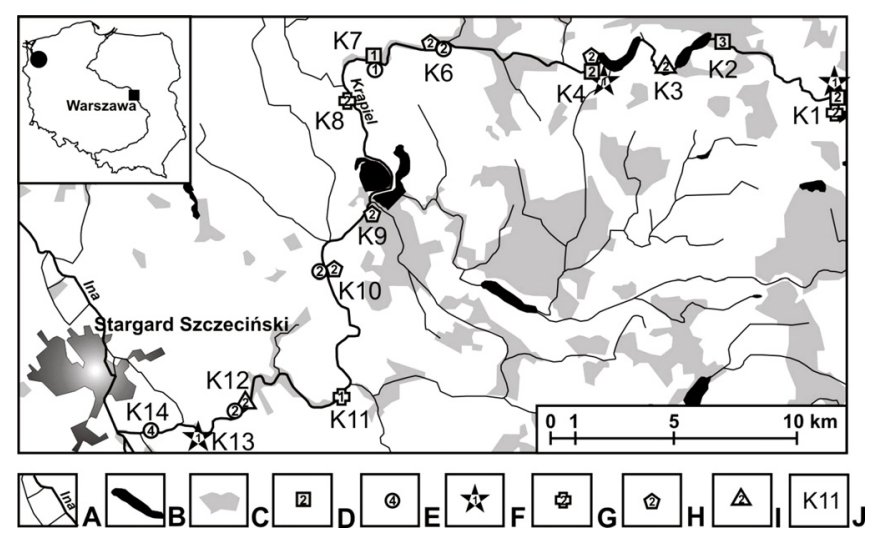

Fig. 1. Location of the sampling sites: A - rivers, B - lakes and fish ponds, C - forests, D-I - sampling sites (numbers inside - number of localities), D - ponds, E - oxbows, F - sedges, G - marshes, H flooded alder woods, I - springs, $\mathrm{J}$ - number of a study site.

Table 2. Landscape types in each catchment.

\begin{tabular}{ll}
\hline Catchment & Landscape type \\
\hline K1 & Mixed, with dominance of forests \\
K2 & Mosaic - meadow, forest, agricultural \\
K3 & Mixed, with dominance of forests \\
K4 & Mixed, with dominance of farmland \\
K6 & Mixed, with dominance of farmland \\
K7 & Mixed, with dominance of farmland \\
K8 & Agricultural \\
K9 & Mosaic - meadow, forest, agricultural \\
K10 & Agricultural \\
K11 & Mixed, with dominance of farmland \\
K12 & Agricultural \\
K13 & Agricultural \\
K14 & Agricultural \\
\hline
\end{tabular}

collinearity were accounted for in the analyses. All calculations were performed in Canoco 4.5 software. The correlation strength was assessed on a scale commonly used in statistics (Sokal and Sneath, 1995).

\section{Results}

\subsection{Landscape characteristics of the studied subcatchments}

Based on collective results presenting the manner of valley land utilization structure, each subcatchment was assigned a specific type of landscape. The uniform (agricultural) type of landscape can be ascribed to following catchments: K8, K10, K12-14). For the remaining catchments, a mixed type of landscape or mosaic of landscapes was found (Tab. 2).

The landscape characteristics of stands (subcatchments) used for description allow for identification of four types of stands of which each shows further internal divisions. It follows from the analysis of similarities between identified subcatchments (Fig. 2) that those identified are grouped at a high degree of similarity of about $98 \%$. The first cluster contains catchments K8, K10, K12, K13 and K14. The highest similarity within this aggregation was found between catchments $\mathrm{K} 8$ and $\mathrm{K} 10$ as well as between $\mathrm{K} 12$ and $\mathrm{K} 13$. The second cluster contains catchments $\mathrm{K} 3$ and $\mathrm{K} 6$, the third one catchments $\mathrm{K} 7$ and $\mathrm{K} 11$ and the fourth - catchments K1, K2, K9.

\subsection{General characteristics of presence of water beetle}

In standing water bodies in the River Krapiel valley, 3573 water beetle individuals were collected (2684 imagines and 889 larvae) representing 112 species belonging to 47 genera and 11 families. The beetles were captured in 10 out of 13 macrohabitats (Tab. 3).

In terms of number of individuals, the most often captured were the following species: Scirtes spp. (14.5\% of collected material), Agabus bipustulatus (6.3\%) and Hydroporus palustris $(5.4 \%)$. The following species were also relatively numerous: Hydrobius fuscipes (4.1\%), Noterus crassicornis (4.0\%), Prionocyphon serricornis (3.9\%), Hydrochara caraboides (3.7\%), Hydroporus incognitus (3.2\%) and Hygrotus inaequalis $(2.6 \%)$. The highest frequency was recorded for the following species: Hydaticus seminiger and $H$. fuscipes $(70 \%$ each) and Agabus paludosus, Colymbetes fuscus, Acilius canaliculatus, $H$. palustris, Anacaena limbata and A. lutescens (60\% each) (Tab. 3).

The highest number of beetle individuals was captured in oxbows $(1,230)$, riverside marshland $(1,058)$, permanent water bodies (718), spring (533), alder swamp forest (28) and sedge (6). The distribution of species richness looks different: the highest numbers of beetle species were found in riverside marshlands (79), permanent water bodies (65) and springs (51) and, clearly less - in the alder swamp forest (16) and sedges (4) (Tab. 3).

The clearly most numerous were stagnobionts " $\mathrm{b}$ " $(75.1 \%$ of captured individuals), whereas the stagnobionts "a" (21.9\%) were less numerous. The contribution of other ecological groups: rheophiles $(2.2 \%)$, rheobionts $(0.25 \%)$ and crenophiles $(0.6 \%)$ was negligible. Most species belonged to the stagnobiont "b" group (68) and the stagnobiont "a" group (36). 7 species were identified as rheophiles, four as rheobionts, and two as crenophiles.

Having analyzed the share of the identified groups of beetle species in each type of waters, greatest quantitative significance was demonstrated by the stagnobiont "b" group. In oxbows, this group of species accounted for as much as $80.9 \%$ of all collected specimens, and had only a slightly smaller share $(>70 \%)$ in permanent water bodies, headwaters and marshes. A visibly smaller share of stagnobionts "a" was noted, with the group constituting $27 \%$ of all collected specimens in headwaters, $26.3 \%$ in permanent waters, $20.8 \%$ in marshes, and $17.6 \%$ in oxbows. Rheophiles, caught only in small quantities, were mostly present in riverine marshes (4.2\% of beetles collected in this place) and in oxbows (1.3\%). Rheobionts were represented by singular species in most of the studied types of water bodies, whereas crenophiles were present only in flooded alder swamp forests $(3.6 \%)$, headwaters $(2.6 \%)$ and marshes $(0.2 \%)$. 


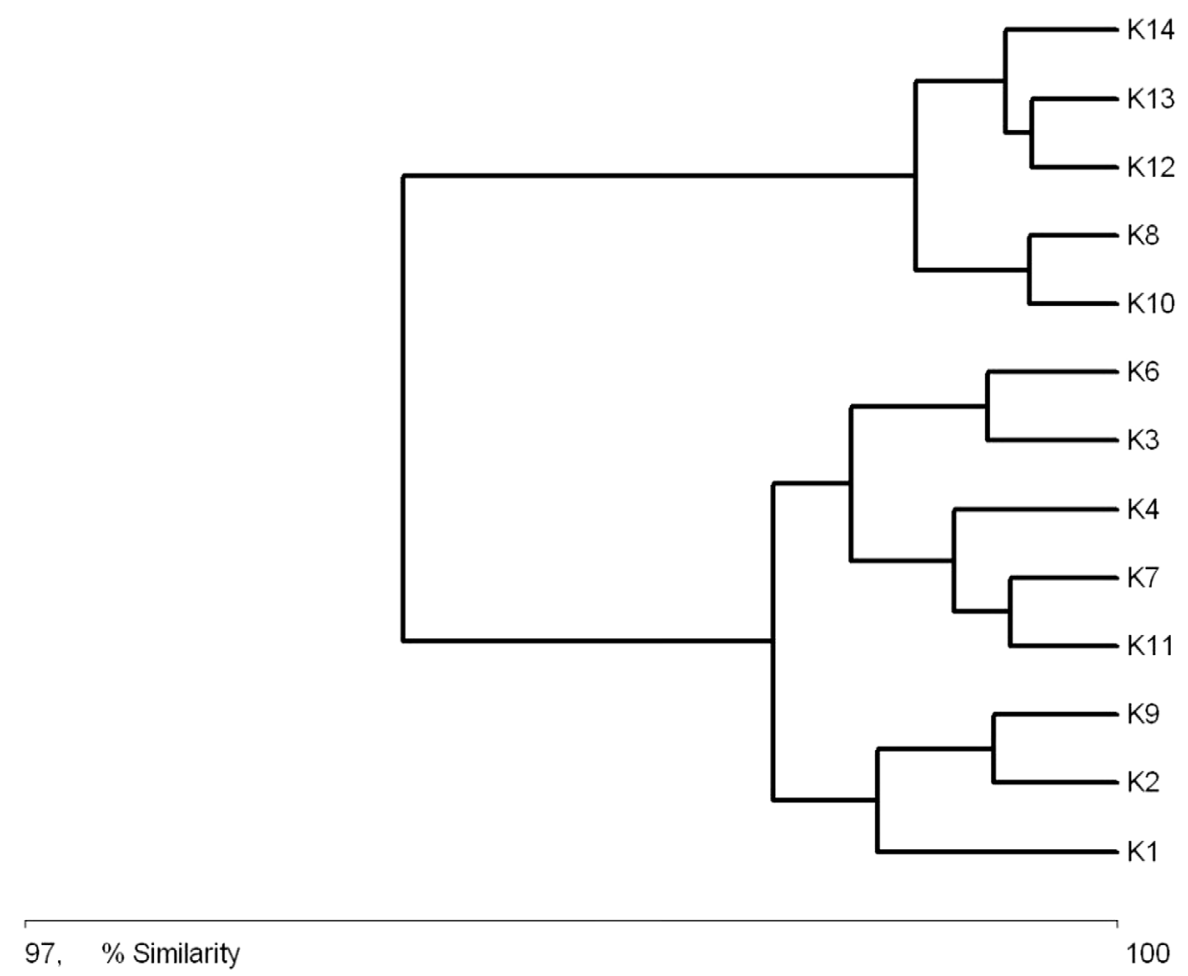

Fig. 2. Similarities of partial drainage basins estimated on the basis of analyzed landscape parameters.

\subsection{Faunistic similarities between selected types of waters and macrohabitats}

The faunistic similarity coefficient between the studied types of water bodies ranged from very low $(0.9 \%)$ to low (32.5\%) (Fig. 3). The selected types of waters can be easily grouped into three, poorly developed clusters with two types of environments each. The strongest similarity is demonstrated by the beetle fauna of riverine marshes and that of permanent water bodies $(32.5 \%)$ - sharing 18 out of a total of 98 identified species. The most numerous were: A. bipustulatus (143 individuals), N. crassicornis (125) and Agabus undulatus (53). Almost identical similarities were noted between clusters of beetles inhabiting springs and inhabiting oxbows (32.4\%). In this case, only 39 out of a total of 91 identified species were present in both ecosystems. The most numerous were: Scirtes spp. (503 individuals), H. fuscipes (97), A. bipustulatus (76) and Acilius sulcatus (71). Comparable similarity values were recorded for clusters of beetles in oxbows and in riverine marshes $(32.2 \%)$. Out of a total of 111 species, 57 were shared by both ecosystems. The most numerous were: Scirtes spp. (492 individuals), A. bipustulatus (192), N. crassicornis (141) and $A$. sulcatus (81). Lowest similarity was recorded for clusters of beetles inhabiting sedges and those inhabiting permanent water bodies $(0.3 \%)$, riverine marshes $(0.9 \%)$ and oxbows $(0.9 \%)$.

The distinguished subcatchments (study sites) are grouped into four clusters demonstrating poor similarity (Fig. 4). The first cluster includes only the fauna of subcatchments K7; the second - that of K4 and K13; the third - that of K3 and K9, followed by the most developed, fourth cluster - encompassing subcatchments $\mathrm{K} 1, \mathrm{~K} 2, \mathrm{~K} 6, \mathrm{~K} 8$ and $\mathrm{K} 12$. The highest faunistic similarity values were recorded for subcatchments
K8 and K12 (34.6\%). Out of the 86 species observed at these sites, 34 appeared to be shared by both ecosystems. The most numerous included: $N$. crassicornis (67 individuals), $A$. undulatus (53), Hydraena palustris (50) and A. limbata (47). The majority of those species represent the stagnobiont "b" group. A slightly lower similarity was noted when comparing subcatchments K1 and K8 (32.1\%), where out of the 105 species identified, 41 appeared to be present in both environments. The visibly most numerous species included: $H$. palustris (172), A. bipustulatus (148) and N. crassicornis (125). Even less faunistic similarity was observed between groups of subcatchments K6 and K8 (26.1\%). Out of the 93 species identified in total in both subcatchments, 48 were shared. The most numerous were: Scirtes spp. (482), $H$. fuscipes (89) and A. sulcatus (75).

The assignment of the study sites to clusters distinguished per landscape characteristics (Fig. 2) is not compliant with the assignment of those study sites to clusters obtained in the course of grouping similarity values of the quantitative structure of species of the studied groups of beetles (Fig. 4) (sign test: $Z=0.35, p=0.72$ ). Only 2 out of 10 study sites (K1 and $\mathrm{K} 2$ ) have the same ordination.

\subsection{Presence of beetles against landscape and habitat factors}

The CCA performed on the impact of the catchment's features (catchment area and the area of each of the catchment's patches) on the distribution of water beetles shows that statistical significance $(p<0.05)$ is demonstrated only for five variables - "a field" (area of arable lands), "a river" (the river's area), "a marsh" (area of marshes), "a forest" (area of forests) and "Cr" (compactness) (Fig. 5). The variables 
Table 3. Aquatic beetles recorded in stagnant waters in the valley of the River Krapiel. Abbr. - abbreviation, E - synecological element ( $\mathrm{kr}$ - krenophile, $\mathrm{rb}$ - rheobiont, re - rheophile, sa - "a" type stagnobiont, sb - "b" type stagnobiont), K1-K13-macrohabitats (like in the Fig. 1), rp - riparian pools, Ox - oxbows, Se - sedges, Ac - alder carrs, Pp - permanent ponds, Sp - springs.

\begin{tabular}{|c|c|c|c|c|c|c|c|c|c|c|c|c|c|c|c|c|c|c|}
\hline \multirow[t]{2}{*}{ Species } & \multirow[t]{2}{*}{ Abbr. } & \multirow[t]{2}{*}{$\mathrm{E}$} & \multicolumn{10}{|c|}{ Macrohabitat } & \multicolumn{6}{|c|}{ Kind of water body } \\
\hline & & & $\mathrm{K} 1$ & $\mathrm{~K} 2$ & K3 & K4 & K6 & K7 & K8 & K9 & $\mathrm{K} 12$ & K13 & $\mathrm{Rp}$ & $\mathrm{Ox}$ & $\mathrm{Se}$ & $\mathrm{Ac}$ & $\mathrm{Pp}$ & $\mathrm{Sp}$ \\
\hline \multicolumn{19}{|l|}{ Gyrinidae } \\
\hline Gyrinus substriatus & Gyr sub & $\mathrm{sb}$ & & & 3 & & 2 & & & & & & & & & 2 & & 3 \\
\hline \multicolumn{19}{|l|}{ Haliplidae } \\
\hline Haliplus confinis & Hal con & $\mathrm{sa}$ & & & & & & & 1 & & & & 1 & & & & & \\
\hline H. flavicollis & Hal fla & re & & & & & & & 2 & & & & 2 & & & & & \\
\hline H. fluviatilis & Hal flu & re & 1 & & & & 6 & & 5 & & & & 5 & 5 & & 1 & 1 & \\
\hline H. heydeni & Hal hey & $\mathrm{sb}$ & 2 & & & & 1 & & 2 & & & & 3 & 1 & & & 1 & \\
\hline H. ruficollis & Hal ruf & $\mathrm{sb}$ & 16 & & & & & & & & & & 1 & & & & 15 & \\
\hline H. sibiricus & Hal sib & $\mathrm{sb}$ & 1 & & & & & & & & & & & & & & 1 & \\
\hline Haliplus sp. & - & $\mathrm{sb}$ & 1 & & & & & & & & & & 1 & & & & & \\
\hline \multicolumn{19}{|l|}{ Noteridae } \\
\hline Noterus clavicornis & Not cla & $\mathrm{sb}$ & 1 & & & & & & 6 & & & & 7 & & & & & \\
\hline N. crassicornis & Not cra & $\mathrm{sb}$ & 75 & & & & & & 50 & & 17 & & 124 & 17 & & & 1 & \\
\hline \multicolumn{19}{|l|}{ Dytiscidae } \\
\hline Agabus biguttatus & Aga big & $\mathrm{kr}$ & & 13 & 1 & & & & & 1 & & & & & & 1 & & 14 \\
\hline A. bipustulatus & Aga bip & $\mathrm{sb}$ & 142 & 11 & & & 31 & & 6 & & 34 & & 142 & 50 & & & 6 & 26 \\
\hline A. chalconatus & Aga chal & $\mathrm{sb}$ & & 1 & & & & & & & & & & & & & & 1 \\
\hline A. congener & Aga con & $\mathrm{sb}$ & & & & & 1 & & & & & & & 1 & & & & \\
\hline A. didymus & Aga did & $\mathrm{kr}$ & & & & & & & 2 & & & & 2 & & & & & \\
\hline A. fuscipennis & Aga Fus & $\mathrm{sb}$ & & 3 & & & & & & & & & & & & & & 3 \\
\hline A. labiatus & Aga lab & $\mathrm{sb}$ & & & & & & & & & 1 & & & 1 & & & & \\
\hline A. nebulosus & Aga neb & $\mathrm{sb}$ & 2 & & & & & & & & & & & & & & 2 & \\
\hline A. neglectus & Aga neg & $\mathrm{sb}$ & & 2 & & & 1 & 2 & & & & & & 3 & & & & 2 \\
\hline A. paludosus & Aga pal & re & & & 5 & & 2 & & 8 & 1 & 5 & 1 & 8 & 7 & 1 & 1 & & 5 \\
\hline A. sturmii & Aga stu & $\mathrm{sb}$ & & & & & 1 & & & & & & & 1 & & & & \\
\hline Agabus sp. & - & $\mathrm{sb}$ & 71 & 9 & 6 & & 4 & & 7 & & 6 & & 76 & 5 & & 2 & 2 & 18 \\
\hline A. undulatus & Aga und & $\mathrm{sb}$ & 12 & & & & 2 & & 51 & & 2 & & 51 & 4 & & & 12 & \\
\hline Ilybius ater & Ily ater & sa & 13 & & & & 14 & 3 & 3 & & & & 8 & 16 & & 1 & 8 & \\
\hline I. erichsoni & Ily eri & $\mathrm{sb}$ & & & & & & 1 & & & & & & 1 & & & & \\
\hline I. fenestratus & Ily fen & re & & & & & 2 & & & & & & & 2 & & & & \\
\hline I. fuliginosus & Ily ful & $\mathrm{sb}$ & & 3 & & & 12 & & 4 & & 4 & & 4 & 15 & & & & 4 \\
\hline I. quadriguttatus & Ily qua & sa & 7 & 1 & & & 1 & & 1 & & & & 4 & 1 & & & 4 & 1 \\
\hline I. similis & Ily sim & sa & & & 2 & & 2 & & 3 & & & & 3 & 2 & & & & 2 \\
\hline Ilybius sp. & - & $\mathrm{sa}$ & 5 & & & & & & & & & & & & & & 5 & \\
\hline I. subaeneus & Ily sub & sa & 2 & & & & & & 1 & & & & 1 & & & & 2 & \\
\hline Platambus maculatus & Pla mac & re & & & & & 1 & & 3 & & & & 3 & 1 & & & & \\
\hline Colymbetes fuscus & Col fus & $\mathrm{sb}$ & 39 & & & & 4 & & 9 & 4 & 3 & 1 & 10 & 7 & & 4 & 38 & \\
\hline C. paykulli & Col pay & sa & & 11 & & 1 & 3 & & & & & & 1 & 3 & & & 0 & 11 \\
\hline C. striatus & Col str & $\mathrm{sa}$ & 19 & & & 1 & 4 & & 28 & & & 2 & 31 & 6 & & & 17 & \\
\hline Rhantus bistriatus & Rha bis & $\mathrm{sb}$ & & & & & & & & & 1 & & & 1 & & & & \\
\hline R. exsoletus & Rha exo & $\mathrm{sb}$ & 6 & & & & 1 & & & & & & & 1 & & & 6 & \\
\hline R. frontalis & Rha fro & $\mathrm{sb}$ & 6 & & & & & & 10 & & & & 11 & & & & 5 & \\
\hline R. notaticollis & Rha not & $\mathrm{sb}$ & & & & & & & 2 & & & & 2 & & & & & \\
\hline R. saturalis & Rha sat & $\mathrm{sb}$ & 7 & & 1 & & 3 & & 4 & & 2 & & 6 & 4 & & & 5 & 2 \\
\hline Rhantus sp. & - & $\mathrm{sb}$ & 2 & 2 & 1 & & 1 & & 1 & & & & 2 & 1 & & & 1 & 3 \\
\hline Acilius canaliculatus & Aci can & sa & 22 & 18 & & 5 & 10 & & 10 & & 1 & & 15 & 11 & & & 22 & 18 \\
\hline A. sulcatus & Aci sul & $\mathrm{sb}$ & 27 & 1 & & & 70 & & 5 & & & & 5 & 70 & & & 27 & 1 \\
\hline Acilius sp. & - & sa & 1 & & & & 3 & 1 & & & & & 1 & 4 & & & & \\
\hline Graphoderus austriacus & Gra aus & $\mathrm{sb}$ & 1 & & & & & & 9 & & & & 9 & & & & 1 & \\
\hline
\end{tabular}


Table 3. (continued).

\begin{tabular}{|c|c|c|c|c|c|c|c|c|c|c|c|c|c|c|c|c|c|c|}
\hline \multirow[t]{2}{*}{ Species } & \multirow[t]{2}{*}{ Abbr. } & \multirow[t]{2}{*}{$\mathrm{E}$} & \multicolumn{10}{|c|}{ Macrohabitat } & \multicolumn{6}{|c|}{ Kind of water body } \\
\hline & & & K1 & $\mathrm{K} 2$ & K3 & K4 & K6 & K7 & K8 & K9 & K12 & K13 & $\mathrm{Rp}$ & $\mathrm{Ox}$ & $\mathrm{Se}$ & $\mathrm{Ac}$ & $\mathrm{Pp}$ & $\mathrm{Sp}$ \\
\hline G. cinereus & Gra cin & $\mathrm{sb}$ & & & & & 2 & & 2 & & & & 2 & 2 & & & & \\
\hline Cybister lateralimarginalis & Cyb lat & $\mathrm{sb}$ & & & & & & & 2 & & & & 2 & & & & & \\
\hline Dytiscus circumcinctus & Dyt cir & $\mathrm{sb}$ & 3 & 1 & & & & & & & & & & & & & 3 & 1 \\
\hline D. dimidiatus & Dyt dim & $\mathrm{sb}$ & 35 & 1 & & & 5 & & 2 & & 2 & & 10 & 7 & & & 27 & 1 \\
\hline D. marginalis & Dyt marg & $\mathrm{sb}$ & 9 & & & & & 2 & 1 & & 6 & & 4 & 8 & & & 6 & \\
\hline Dytiscus sp. & - & $\mathrm{sb}$ & 5 & & & & & & & & & & & & & & 5 & \\
\hline Hydaticus aruspex & Hyd aru & $\mathrm{sb}$ & 1 & & & & & & & & & & & & & & 1 & \\
\hline H. seminiger & Hyd sem & $\mathrm{sb}$ & 5 & 17 & & 1 & 2 & 7 & 18 & & & 3 & 24 & 10 & 2 & & & 17 \\
\hline H. continentalis & Hyd con & $\mathrm{sb}$ & 2 & & & & & & & & & & & & & & 2 & \\
\hline H. transversalis & Hyd tra & $\mathrm{sb}$ & 14 & 2 & & & 1 & & 18 & & & & 18 & 1 & & & 14 & 2 \\
\hline Hydaticus sp. & - & $\mathrm{sb}$ & 1 & & & & & & & & & & 1 & & & & & \\
\hline Hydroglyphus geminus & Hyd gem & sa & & & & & & & 6 & & & & 6 & & & & & \\
\hline Graptodytes bilineatus & Gra bil & $\mathrm{sb}$ & & & & & & & & & 1 & & & 1 & & & & \\
\hline Hydroporus angustatus & Hyd ang & sa & 17 & & & & 16 & & 11 & & 1 & & 19 & 17 & & & 9 & \\
\hline H. erytrocephalus & Hyd ery & sa & 10 & & & & 8 & & 2 & & 12 & & 3 & 19 & & & 9 & 1 \\
\hline H. incognitus & Hyd inc & sa & 48 & 15 & & & 10 & & 19 & & 22 & & 21 & 21 & & 2 & 46 & 24 \\
\hline H. melanarius & Hyd mel & sa & & & & & & & & & 2 & & & & & & & 2 \\
\hline H. memnonius & Hyd mem & sa & 1 & & & & & & & & & & & & & & 1 & \\
\hline H. morio & Hyd mor & sa & & & & & 4 & & 1 & & 6 & 2 & 1 & 3 & 2 & 2 & & 5 \\
\hline H. nigrita & Hyd nig & sa & & 2 & & & & & & & 7 & & & & & & & 9 \\
\hline H. obscurus & Hyd obs & sa & & 1 & & & 7 & & 1 & 1 & 2 & & 1 & 8 & & 1 & & 2 \\
\hline H. palustris & Hyd pal & $\mathrm{sb}$ & 167 & 3 & & & 4 & 1 & 6 & & 11 & & 43 & 6 & & & 130 & 13 \\
\hline H. planus & Hyd pla & sa & 6 & & & & & & & & & & 3 & & & & 3 & \\
\hline H. rufifrons & Hyd ruf & sa & & 1 & & & 3 & & & & 4 & & & 4 & & & & 4 \\
\hline H. striola & Hyd str & sa & 2 & & & & 16 & & 4 & & 4 & & 4 & 20 & & & 2 & \\
\hline Hydroporus sp. & - & sa & & & & & & & 3 & & & & 3 & & & & & \\
\hline Porhydrus lineatus & Por lin & sa & & & & & & & 2 & & & & 2 & & & & & \\
\hline Suphrodytes dorsalis & Sup Dor & $\mathrm{sb}$ & 5 & & & & 2 & & & & & & & 2 & & & 5 & \\
\hline S. figuratus & Sup fig & $\mathrm{sb}$ & & & & & 2 & & 5 & & & & 5 & 2 & & & & \\
\hline Hygrotus decoratus & Hyg dec & sa & 10 & 3 & & & 3 & & 1 & & & & 1 & 3 & & & 10 & 3 \\
\hline H. impressopunctatus & Hyg imp & $\mathrm{sb}$ & 17 & & & & & & 4 & & 2 & & 8 & 2 & & & 13 & \\
\hline H. inaequalis & Hyg ine & $\mathrm{sb}$ & 67 & & 1 & & 8 & 1 & 17 & & 1 & & 25 & 10 & & & 59 & 1 \\
\hline Hygrotus sp. & - & $\mathrm{sb}$ & 2 & & & & & & & & & & & & & & 2 & \\
\hline Hyphydrus ovatus & Hyp ova & $\mathrm{sb}$ & 13 & & & & 1 & & 6 & & & & 6 & 1 & & & 13 & \\
\hline Laccophilus hyalinus & Lac hal & re & & & & & & & 26 & & & & 26 & & & & & \\
\hline L. minutus & Lac min & $\mathrm{sb}$ & 10 & & & & & & 1 & & & & 11 & & & & & \\
\hline Helophoridae & & & & & & & & & & & & & & & & & & \\
\hline Helophorus brevipalpis & Hel bre & sa & & & & & & & & & 2 & & & & & & & 2 \\
\hline H. flavipes & Hel fla & sa & 5 & & & & & & & & & & 4 & & & & 1 & \\
\hline H. granularis & Hel gra & sa & & 2 & & & 4 & & 6 & & 2 & & 6 & 4 & & & & 4 \\
\hline H. griseus & Hel gri & sa & 4 & 2 & 1 & & 8 & & 2 & & 3 & & 3 & 9 & & & 3 & 5 \\
\hline H. minutus & Hel min & sa & & & & & 1 & & & & & & & 1 & & & & \\
\hline H. pumilio & Hel pum & sa & 1 & 2 & & & & & & & & & 1 & & & & & 2 \\
\hline Hydrochidae & & & & & & & & & & & & & & & & & & \\
\hline Hydrochus brevis & Hyd bre & $\mathrm{sb}$ & & & & & & & 3 & 1 & & & 3 & & & 1 & & \\
\hline H. crenatus & Hyd cre & $\mathrm{sb}$ & 3 & & & & & & & & & & & & & & 3 & \\
\hline Spercheidae & & & & & & & & & & & & & & & & & & \\
\hline Spercheus emarginatus & Spe ema & $\mathrm{sb}$ & & & & & & & & & 1 & & & 1 & & & & \\
\hline Hydrophilidae & & & & & & & & & & & & & & & & & & \\
\hline Anacaena globulus & Ana glo & $\mathrm{sb}$ & 1 & & & & & & & & & & 1 & & & & & \\
\hline A. limbata & Ana lim & $\mathrm{sb}$ & 4 & 1 & 2 & & 16 & & 37 & & 10 & & 40 & 17 & & 1 & 1 & 11 \\
\hline
\end{tabular}


Table 3. (continued).

\begin{tabular}{|c|c|c|c|c|c|c|c|c|c|c|c|c|c|c|c|c|c|c|}
\hline \multirow[t]{2}{*}{ Species } & \multirow[t]{2}{*}{ Abbr. } & \multirow[t]{2}{*}{$\mathrm{E}$} & \multicolumn{10}{|c|}{ Macrohabitat } & \multicolumn{6}{|c|}{ Kind of water body } \\
\hline & & & $\mathrm{K} 1$ & $\mathrm{~K} 2$ & $\mathrm{~K} 3$ & K4 & K6 & K7 & K8 & K9 & K12 & K13 & $\mathrm{Rp}$ & Ox & $\mathrm{Se}$ & Ac & $\mathrm{Pp}$ & $\mathrm{Sp}$ \\
\hline A. lutescens & Ana lut & sa & 17 & 15 & & & 7 & & 10 & 2 & 5 & & 13 & 9 & & 2 & 14 & 18 \\
\hline Berosus sp. & - & $\mathrm{sb}$ & & & & & & & 1 & & & & 1 & & & & & \\
\hline Cymbiodyta marginella & Cym mar & sa & 24 & 1 & & & 1 & & & & & & 2 & 1 & & & 22 & 1 \\
\hline Enochrus coarctatus & Eno coa & sa & 11 & & & & 1 & & 4 & & & & 6 & 1 & & & 9 & \\
\hline E. halophilus & Eno hal & sa & & & & & 1 & & & & & & & 1 & & & & \\
\hline E. melanocephalus & Eno mel & sa & & 1 & 1 & & 6 & & 50 & & 1 & & 50 & 5 & & 2 & & 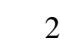 \\
\hline E. quadripunctatus & Eno qua & $\mathrm{sb}$ & 4 & & & & & & 4 & & & & 6 & & & & 2 & \\
\hline E. testaceus & Eno tes & $\mathrm{sb}$ & 3 & & & & & & & & & & 2 & & & & 1 & \\
\hline Helochares obscurus & Hel obs & $\mathrm{sb}$ & 5 & & & & 12 & & 10 & & 6 & & 14 & 18 & & & 1 & \\
\hline Hydrobius fuscipes & Hyd fus & $\mathrm{sb}$ & 24 & 13 & 7 & & 67 & & 22 & 2 & 12 & & 34 & 74 & & 4 & 12 & 23 \\
\hline Hydrochara caraboides & Hyd car & $\mathrm{sb}$ & 12 & 34 & & & 51 & 31 & 4 & & 2 & & 12 & 84 & & & 4 & 34 \\
\hline Hydrophilus sp. & - & $\mathrm{sb}$ & 1 & & & & & & & & & & 1 & & & & & \\
\hline Laccobius minutus & Lcc min & sa & & & & & & & 1 & & 12 & & 1 & 4 & & & & 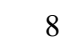 \\
\hline Laccobius sp. & - & sa & & & & & 2 & & 1 & & & & 1 & 2 & & & & \\
\hline Coelostoma orbiculare & Coe orb & $\mathrm{sb}$ & & & & & & & 15 & & & & 15 & & & & & \\
\hline Cercyon bifenestratus & Cer bif & $\mathrm{sb}$ & & & & & & & 1 & & & & 1 & & & & & \\
\hline C. convexiusculus & Cer con & $\mathrm{sb}$ & 1 & & & & 4 & & 4 & & & 1 & 4 & 4 & 1 & & 1 & \\
\hline C. sternalis & Cer ster & $\mathrm{sb}$ & 1 & & & & & & & & & & & & & & 1 & \\
\hline C. tristis & Cer tri & $\mathrm{sb}$ & 2 & & & & & & & & 1 & & & 1 & & & 2 & \\
\hline Hydrophilidae n.det. & - & & 1 & & & & & & & & & & 1 & & & & & \\
\hline Hydraenidae & & & & & & & & & & & & & & & & & & \\
\hline Hydraena palustris & Hyd pls & sa & 2 & 12 & & & 5 & & 4 & & 46 & & 4 & 42 & & 1 & 2 & 20 \\
\hline H. pulchella & Hyd pul & $\mathrm{rb}$ & & & & & & & & & 1 & & & & & & & 1 \\
\hline H. riparia & Hyd rip & $\mathrm{rb}$ & 3 & & & & & & & & & & & & & & 3 & \\
\hline Limnebius atomus & Lim ato & $\mathrm{sb}$ & 10 & & & & & & 4 & & 1 & & 4 & 1 & & & 10 & \\
\hline L. parvulus & Lim par & $\mathrm{sb}$ & 77 & & & & 3 & & 19 & & 23 & & 21 & 11 & & & 75 & 15 \\
\hline L. truncatellus & Lim trun & $\mathrm{rb}$ & 1 & & & & 1 & & & & 3 & & & 3 & & & 1 & 1 \\
\hline Ochthebius minimus & Och min & $\mathrm{sb}$ & 7 & & & & 23 & & 1 & & 22 & & 1 & 27 & & & 7 & 18 \\
\hline Elmidae & & & & & & & & & & & & & & & & & & \\
\hline Limnius sp. & - & $\mathrm{rb}$ & & & & & & & 1 & & & & 1 & & & & & \\
\hline Scirtidae & & & & & & & & & & & & & & & & & & \\
\hline Cyphon sp. & Cyp sp & $\mathrm{sb}$ & & 11 & & & 24 & & & & & & & 24 & & & & 11 \\
\hline Elodes sp. & Elo so & re & & & & & & & & & 11 & & & 7 & & & & 4 \\
\hline Prionocyphon serricornis & Prn ser & $\mathrm{sb}$ & 1 & 124 & 3 & & 12 & & & & & & & 12 & & & 1 & 127 \\
\hline Scirtes spp. & Sci sp & $\mathrm{sb}$ & & 26 & & & 466 & & 16 & & 11 & & 16 & 476 & & & & 27 \\
\hline Curculionidae & & & & & & & & & & & & & & & & & & \\
\hline Tanysphyrus lemnae & Tan lem & $\mathrm{sb}$ & & & & & 1 & & 1 & & 1 & & 1 & 2 & & & & \\
\hline
\end{tabular}

are correlated with the first and second ordination axis, which explain $28.9 \%$ and $23.7 \%$ of the total variability of the species composition respectively. Analyzing the correlation strength of landscape factors and faunistic composition, it is worth to note that for more than 30 species varied in terms of habitat preference these correlations were average and perfectly negative. Positive correlation between landscape factors and the studied species was demonstrated only in the case of 12 species. The majority of these are weak correlations ( $A$. sulcatus, Scirtes spp., Hydroporus striola, H. obscurus, Hydroporus angustatus, Ilybius ater, Haliplus fluviatilis) or average correlations (e.g. H. caraboides).
An analysis of the relation between beetle distribution and river slope, catchment distance from springs and distance of each of the catchment's patches from the river, revealed significant impact of four variables: the strongest - "d marsh" (distance from marshes), with which there is only a very slight correlation of 12 species, including species related to turf waters (I. ater, A. sulcatus, Hydroporus obscurus, H. striola); followed by "d wast" (distance from wasteland); "d shrub" (shrubs); and "d st wat" (distance from water), correlated mainly with stagnobionts (Fig. 6).

The performed CCA on the relation between the characteristics of each of the patches in the buffer zones and the 


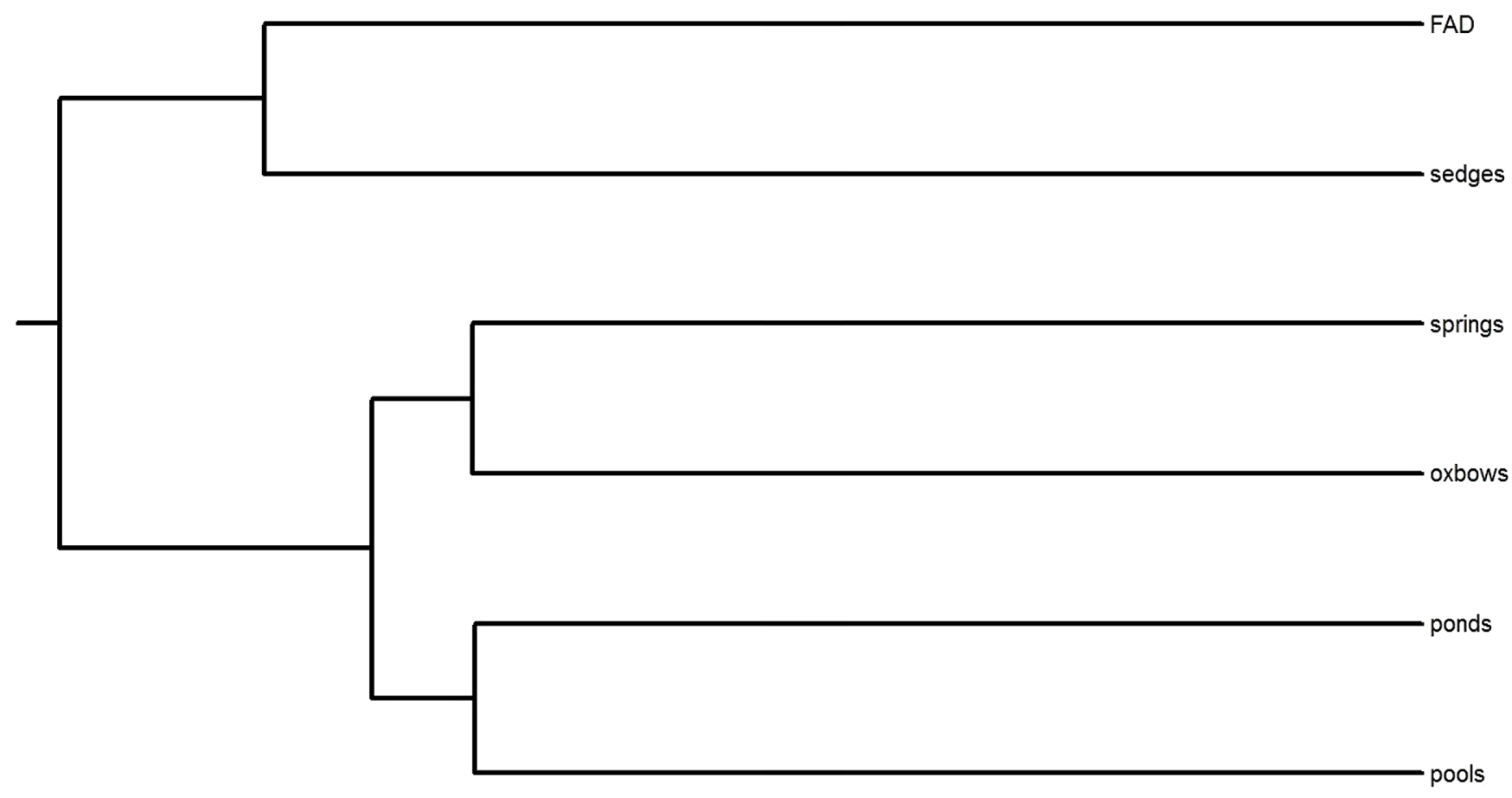

Fig. 3. Dendrogram of faunistic similarities between selected types of waters.

distribution of water beetles shows that statistical significance $(p<0.05)$ is demonstrated only for five variables - PSSD, NUMP, MEDPS, Cr and MSI. The variables are correlated with the first and second ordination axis, which explain $27.4 \%$ and $22.3 \%$ of the total variability of the species composition respectively (Fig. 7). Correlations between species and environmental factors are positive only in the case of 19 species representing all of the researched ecological groups. In most cases these correlations are either weak or average, with the exception of Agabus biguttatus, Colymbetes paykulli and $P$. serricornis, which reveal a strong correlation with PSSD (NUMP in catchment). The remaining species demonstrate a negative, although average and weak relationship with most of the analyzed landscape factors.

The results of the CCA performed on the relation between the beetle fauna's species composition and the characteristics of each of the patches in the buffer zones, reveal a statistically significant $(p<0.05)$ impact of the total area of patches of a given class: $\mathrm{CA}(1)$ - compact civil structures, $\mathrm{CA}(7)-$ mixed coniferous forest; $\mathrm{PD}(12)$ - coniferous forest and distance from measurement point: $\mathrm{L}(11)$ - deciduous forest, and L(17) - watercourse. The variables are correlated with the first and second ordination axis, which explain $27.4 \%$ and $22.3 \%$ of the total variability of the species composition respectively (Fig. 8). 11 species show a positive correlation with $\mathrm{PD}(12)$ and L(11), whereas 11 species show the same with $\mathrm{CA}(13)$ and $\mathrm{L}(17)$. The presence of the remaining species shows a positive correlation with $\mathrm{CA}(1)$. The majority of these relationships are weak or average correlations, with the exception of $A$. biguttatus, C. paykulli, H. caraboides and P. serricornis.

The CCA performed on the impact of the riverbed's structure on the distribution of water beetles shows that statistical significance $(p<0.05)$ is demonstrated in the case of five variables: $\mathrm{M}-$ mean sediment grain size; $\mathrm{W}-$ sorting; Plants - coverage with vegetation; Organic - organic matter; and Mineral - mineral matter (Fig. 9). The variables are correlated with the first and second ordination axis, which explain $30.4 \%$ and $25.9 \%$ of the total variability of the species composition respectively. Almost 30 species demonstrated a positive correlation with vegetation coverage and with organic matter. This group of species shows high ecological diversity: it comprises primarily stagnobionts " $b$ ", along with stagnobionts "a", rheophiles and crenophiles - with the strongest relation apparently demonstrated by Laccophilus minutus, A. bipustulatus and A. biguttatus. The remaining species present a positive correlation with the size of sediment grains and with mineral matter. This group of species is characterized by a significant share of stagnobionts "a" (species of the genera Helophorus, Hydroporus and Laccobius) as well as rheophiles (H. fluviatilis and A. paludosus).

The conducted CCA revealed that among the analyzed physical and chemical properties of the studied waters, statistically significant $(p<0.05)$ impact on the species composition of the beetle group is demonstrated by: temperature 


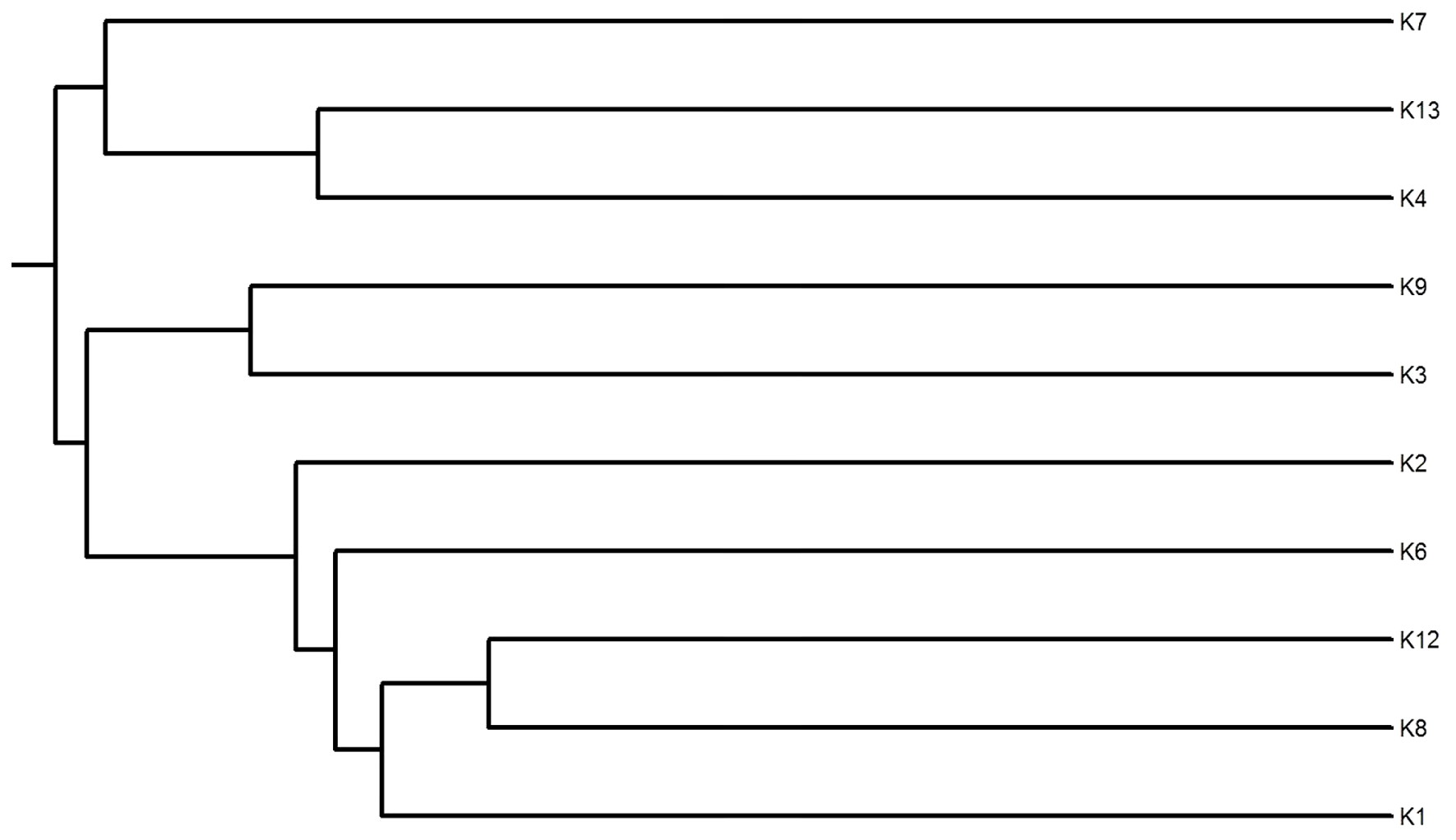

Fig. 4. Dendrogram of faunistic similarities between selected types of subcatchments.

(temp.), saturation $\left(\mathrm{O}_{2}\right)$, electrolytic conductivity (cond.), $\mathrm{BOD}_{5}, \mathrm{pH}$ and $\mathrm{NH}_{4}$ (Fig. 10). The variables are correlated with the first and second ordination axis, which explain $27.6 \%$ and $16.9 \%$ of the total variability of the species composition respectively. A very large group of species shows positive correlation with temperature and with saturation, and negative correlation with $\mathrm{pH}$ and $\mathrm{BOD}_{5}$. These include mainly representatives of the stagnobiont " $b$ " group, along with quite numerous representatives of the "a" group, which are related to less eutrophicated, including acidic, waters. On the other hand, positive correlation with saturation and negative correlation with temperature is demonstrated by 17 species, among which very strong correlation can be assigned to the crenobiont $A$. biguttatus.

\section{Discussion}

Some papers touch on the problem of how environmental factors influence the characteristics of beetle groups found in the various water ecosystems located within the floodplains of rivers (Persson Vinnersten et al., 2009; Pakulnicka and Nowakowski, 2012; Costea et al., 2013). However, only factors of local significance to the water environment had been analyzed. In the meantime, highly mobile organisms and good fliers can be greatly influenced by factors from outside the water environment - forests or compact civil structures that pose a physical barrier limiting dispersion would be one such example. The impact of the land environment on features exhibited by many groups of water organisms is emphasized in, among others, Delettre et al. (1992), Delettre and Morvan (2000) and Galic et al. (2013). Richards and Host (1994) and Richards et al. (1996), on the other hand, point to factors such as landscape structure and landscape utilization as being of major importance in the shaping of water biocenoses.

Still, there is no doubt that the faunistic relations as well as the species richness of a river valley are affected by the diversity of the various water ecosystems found in such places (Stanley et al., 1997; Wissinger, 1999; Junk, 2000; Tockner et al., 2000; Robinson et al., 2002), but also their morphology and hydrological type (Castella et al., 1984).

Apart from the centrally situated river itself, the valley of the Krapiel encompasses oxbows, permanent water bodies, periodic water bodies (riverine marshes, sedges, and flooded alder swamp forests) and headwaters. This diversity of water environments sustains a vast local biodiversity of beetle fauna, the size of which can be compared to that of valleys of much larger lowland rivers - such as the Narew (Biesiadka and Pakulnicka, 2004a), Bug (Przewoźny et al., 2006) or Niemen (Pakulnicka and Nowakowski, 2012). The great species richness of the Krapiel valley's fauna was also observed in other macroinvertebrates (Szlauer-Łukaszewska and Zawal, 


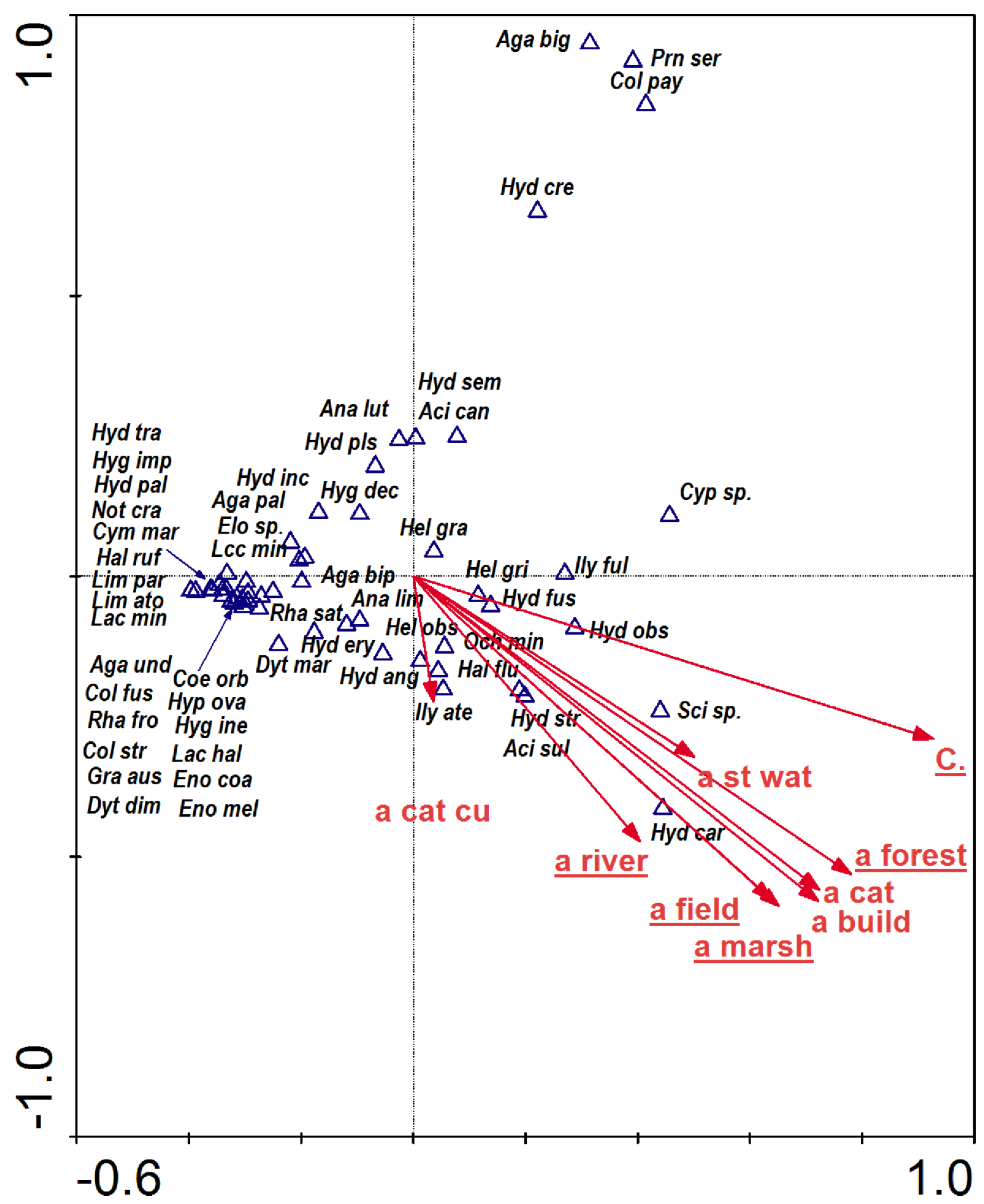

Fig. 5. The CCA ordination plot of occurrence of water beetles in relation to the characteristics of catchment along the first and second CCA axis. Full species names are given in Table 3.

2014; Dąbkowski et al., 2016; Stępień et al., 2015; Zawal et al., 2015; Zawal et al., 2016a-d; Płaska et al., 2016).

Among the mentioned types of water bodies found in the Krapiel valley, the most important role in shaping local faunistic relations is played by oxbows and riverine marshes. It was in these locations where the highest counts of beetles and the highest beetle species richness were recorded, although the river Krapiel itself seems also of major importance to local biodiversity - abundant, and rich in terms of species, faunistic material was collected in the river, comprising 3271 beetles representing 137 species (Dąbkowski et al., unpublished data). The important role in the shaping of a river valley's faunistic relations played by the various water bodies found in valleys, especially oxbows, is further confirmed in studies of Coleoptera inhabiting the valleys of the river Narew (Biesiadka and Pakulnicka, 2004a), Bug (Przewoźny et al., 


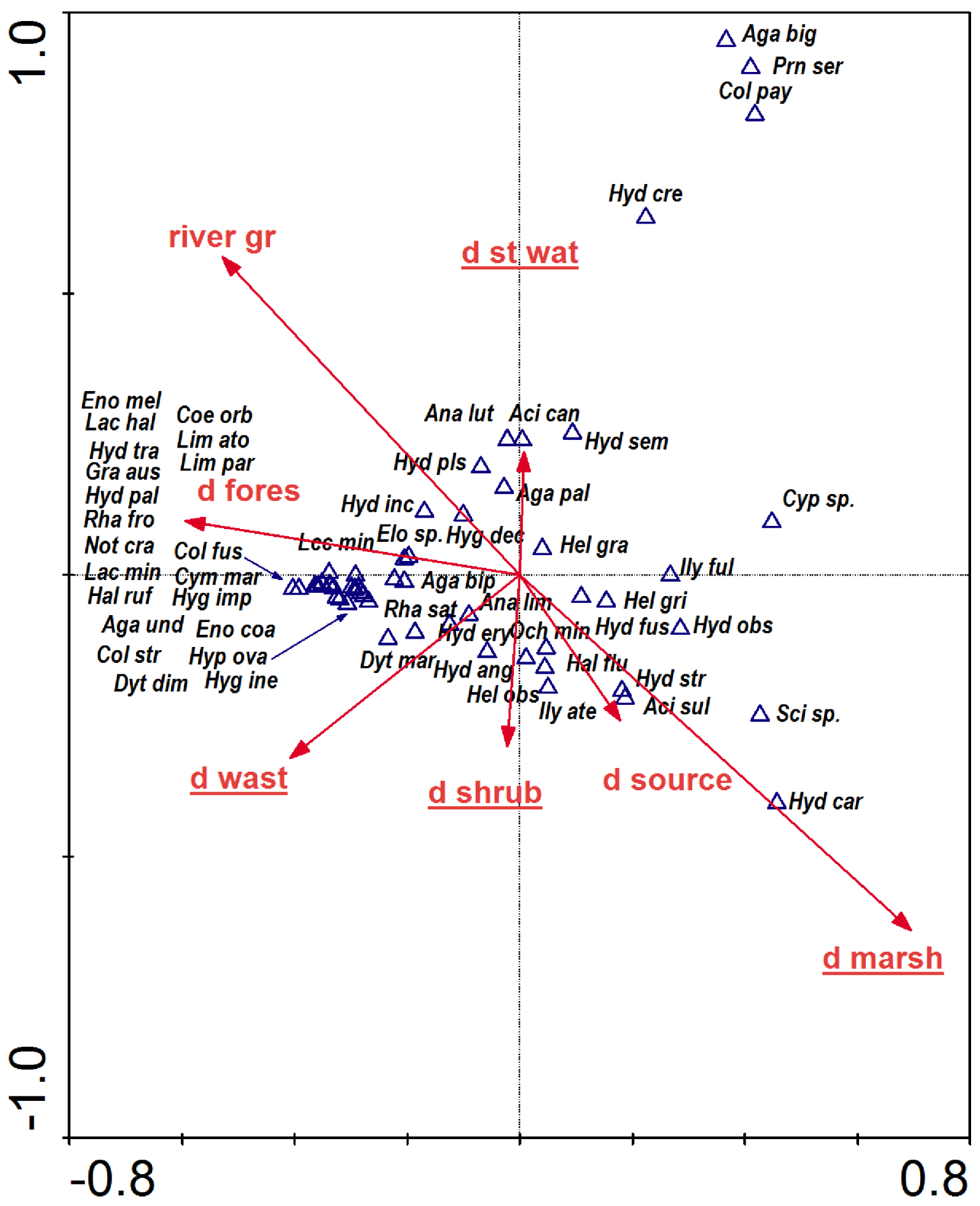

Fig. 6. The CCA ordination plot of occurrence of water beetles in relation to the river gradient, distance of catchment from the river head, and distance of each patch in the catchment from the river along the first and second CCA axis. Full species names are given in Table 3.

2006) and Niemen (Pakulnicka and Nowakowski, 2012). Oxbows are also considered to be of major significance to Hydrachnidae - as attested by Biesiadka and Cichocka (2004) - as well as to aquatic Heteroptera (Biesiadka and Kurzątkowska, 2003).

The similarities between the fauna of individual types of water bodies observed in the Krapiel valley are visibly smaller than those observed in the valleys of the great lowland rivers mentioned above (Biesiadka and Pakulnicka, 2004a; Przewoźny et al., 2006; Pakulnicka and Nowakowski, 2012). The most similar groups of beetle fauna were recorded for: riverine marshes and permanent water bodies, springs and oxbows, and for oxbows and riverine marshes. In all the mentioned pairs of types of water bodies the number of shared species accounted for not more than half of the total number of species identified in both ecosystems. The smallest similarity was recorded in the 


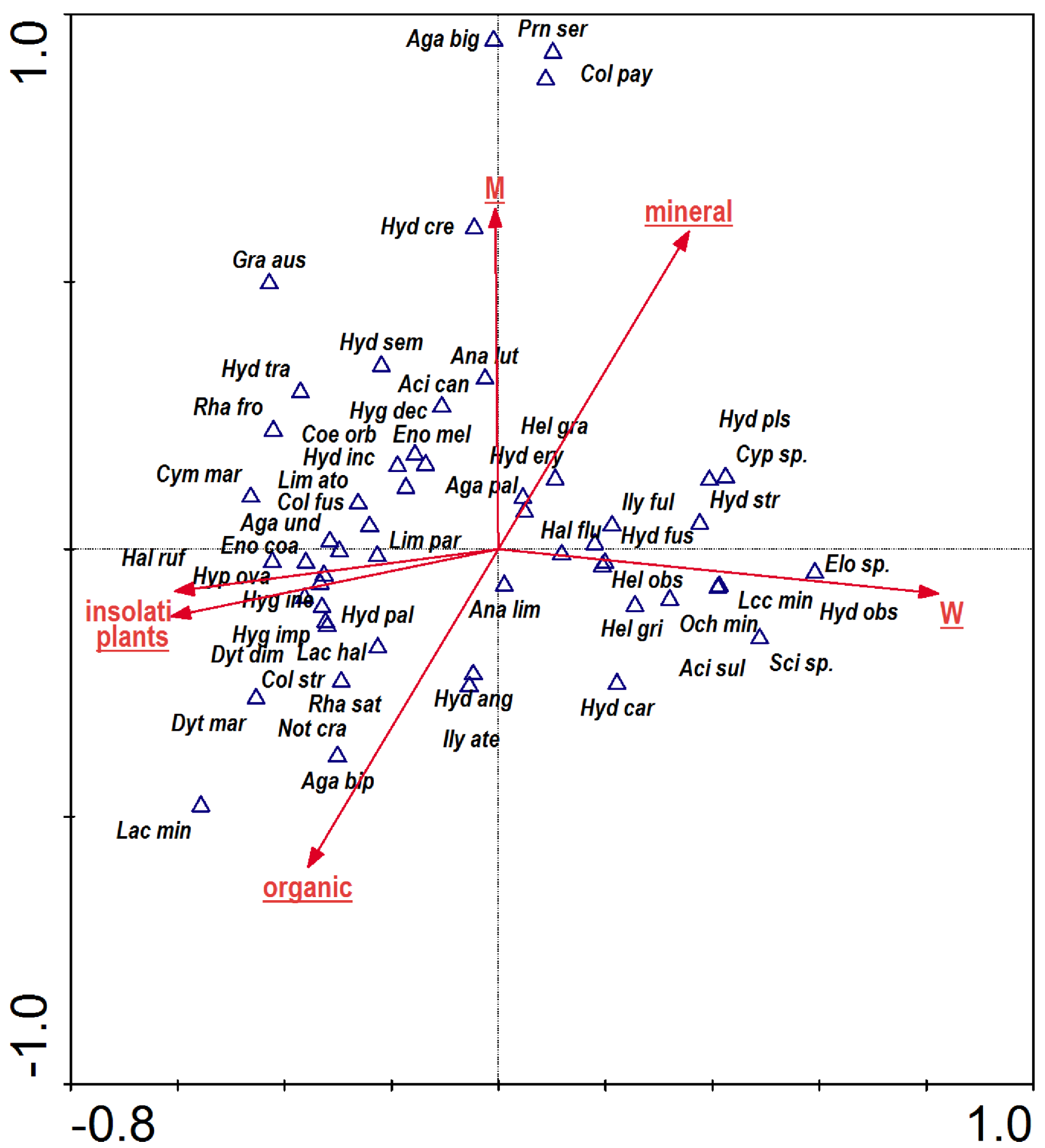

Fig. 7. The CCA ordination plot of occurrence of water beetles in relation to the characteristics of landscape buffer zones along the first and second CCA axis. Full species names are given in Table 3.

pair of sledges and permanent water bodies and the pair of marshes and oxbows.

A likewise small faunistic similarity was observed in groups of beetles at the selected study sites (subcatchments and macrohabitats), which is rather surprising given that these sites share common landscape features. Moreover, the faunistic similarity diagram is noticeably different from the similarity diagram based on landscape characteristics - only two study sites (K1 and K2) shared the same ordination. Similar results were obtained in the case of the Krapiel valley's Hydrachinidae (Zawal et al., 2016c). The causes of such discrepancies may be assigned not only to landscape, but also to the ecosystem itself - considering the environmental features of the analyzed study sites that are in fact the focal points of subcatchments. The subcatchments, when considered separately, vary between each other in the number and diversity of their water 


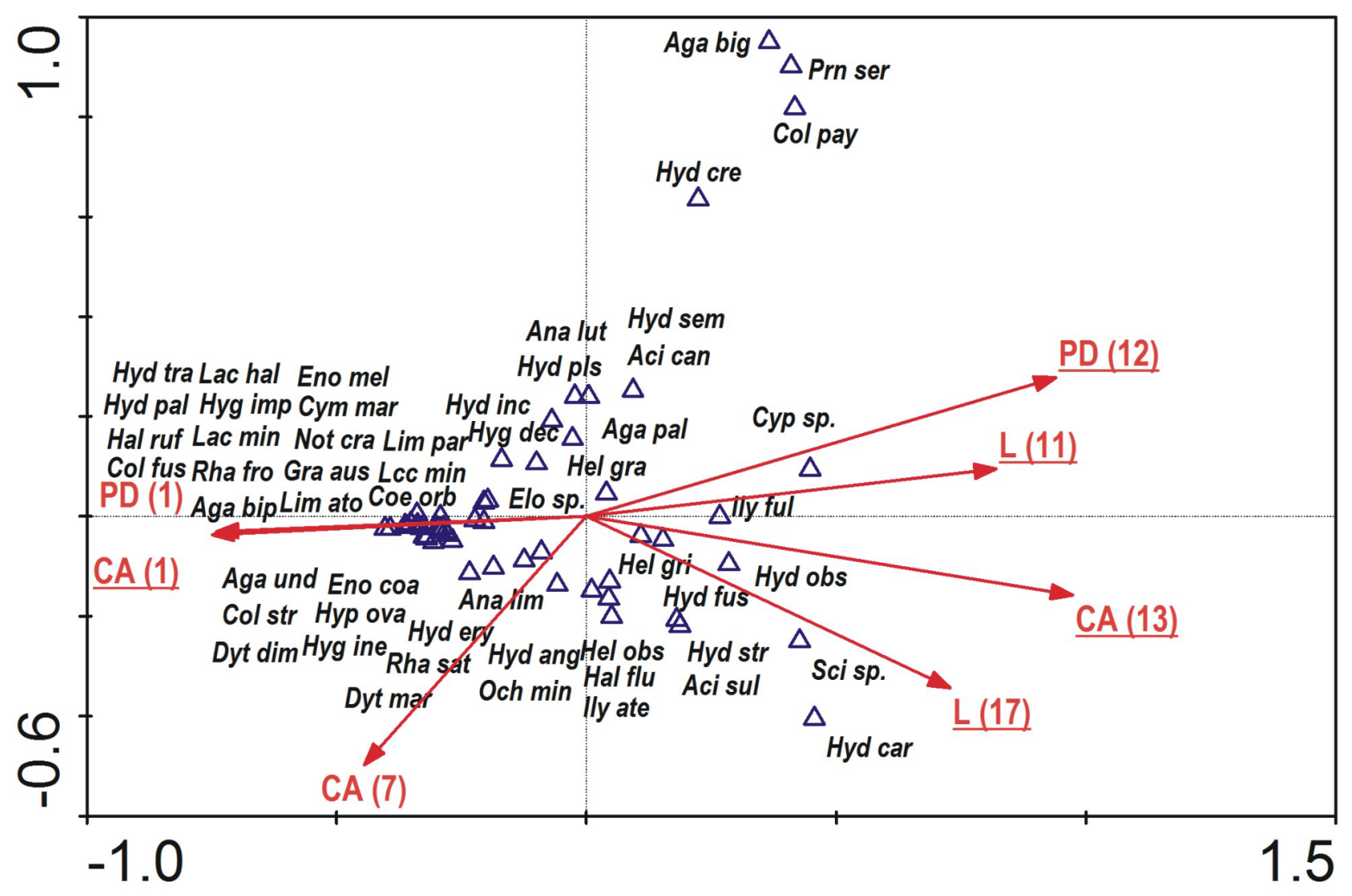

Fig. 8. The CCA ordination plot of occurrence of water beetles in relation to the characteristics of each patch in the buffer zones along the first and second CCA axis. Full species names are given in Table 3.

environments. In subcatchment $\mathrm{K} 1$, where the landscape is dominated by forests, non-overgrown temporary bodies of water are the most common type (marshes and willow shrubs); the remaining subcatchments, shown to be similar in terms of landscape features, included farmland upon permanent water bodies (K8), oxbows (K6) or oxbows and headwaters (K12). The local habitat conditions of these varied types of waters have with no doubt a strong impact on the characteristics of the beetle clusters inhabiting them. Such environmental factors as water periodicity, water flow speed, water body size, type of bottom, degree to which they are overgrown with vegetation, are indicated as key factors shaping the faunistic relations of beetles inhabiting the flooded valley of the river Niemen (Pakulnicka and Nowakowski, 2012); this is true also for other types of landscapes with numerous bodies of water (Koch, 1989; Marchese and Ezcurra de Drago, 1992; Winfield Fairchild et al., 2000; Lundkvist et al., 2001; Oertli et al., 2002; Pakulnicka, 2008; Giora, 2014; Pakulnicka et al., 2015a, b).

The clusters of beetles inhabiting the lentic waters of the Krąpiel valley, unlike e.g. the Niemen valley with its numerous counts of rheophiles (Pakulnicka and Nowakowski, 2012), are dominated by stagnobionts - especially stagnobionts "b" related to more eutrophicated waters. They are also the ecological group with the highest species richness. Stagnobionts " $b$ " are visibly dominant in all of the studied kinds of the Krapiel valley's water bodies, most notably in oxbows and in permanent waters, springs and riverine marshes. A small quantitative share and poor species richness, both for the material in general and for the individual types of water bodies, was demonstrated by beetles related to less eutrophicated lentic waters (stagnobionts "a"). Surprisingly, the share of rheophiles, rheobionts and crenophiles was also minor - with such species being recorded exclusively in oxbows and riverine marshes, while their share in the Krapiel itself accounted for $12.4 \%$ of the collected material (Dąbkowski et al., in press). By comparison, the largest share in beetle clusters found in the oxbows of the valley of the River Niemen (Pakulnicka and Nowakowski, 2012), despite poor species diversity, comprised stagnobionts "a" as well as rheophiles and rhebionts, accounting in total for almost $70 \%$ of all collected beetles - which is only slightly less than the share of the Krąpiel valley's stagnobionts " $b$ " alone. A similarly significant quantitative share of these groups of species was observed in the oxbows of the Narew river (Biesiadka and Pakulnicka, 2004a); only slightly smaller - in the valley of the River Bug (Przewoźny et al., 2006); and an even greater share was noted for the river Niemen itself and in its largest tributaries. Interestingly, Niemen's smaller tributaries are characterized by the largest share of rheobionts (80\%) and of stagnobionts "a" (Pakulnicka and Nowakowski, 2012). With all certainty, the nature of the valley of the River Krapiel, especially its depth and narrowness, result in either periodical floods of the river being somewhat rare or the range of floods is limited and does not reach the valley's other water bodies such as oxbows and permanent waters. This poses a limitation to the hydrological 


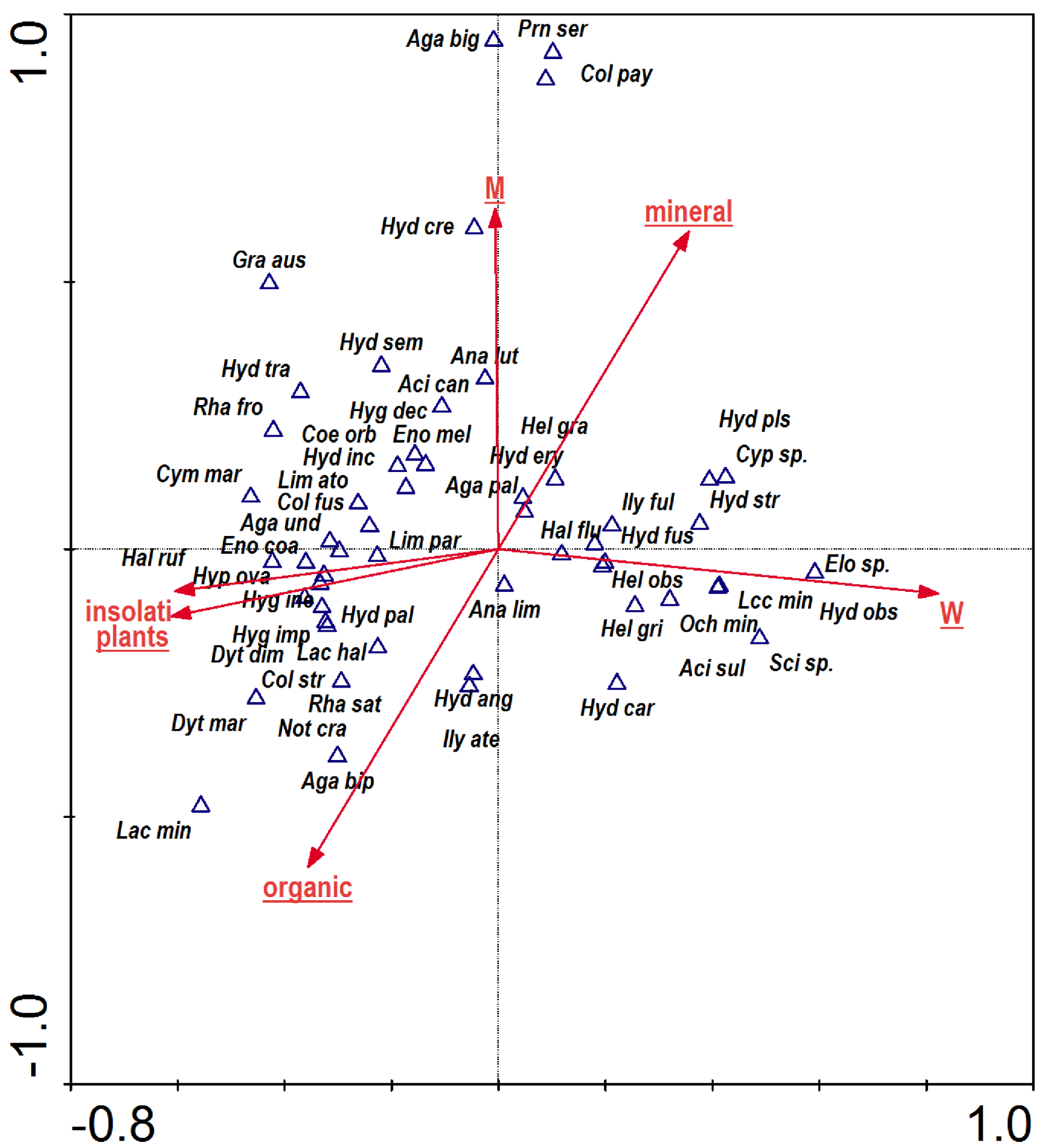

Fig. 9. The CCA ordination plot of occurrence of water beetles in relation to the structure of the riverbed along the first and second CCA axis. Full species names are given in Table 3.

connectivity of the valley's water bodies and, consequently, also to beetle migration over water. A similar phenomenon was observed in the valley of the Narew (Biesiadka and Pakulnicka, 2004a), where a long-term drop in ground water levels restricted hydrological contact between the valley's water bodies, contributing to the deterioration of differences in groups of beetles and their achievement of faunistic individuality. Domination of beetles related to standing waters in the fauna composition is a typical effect of limited hydrological contact between valley water bodies and the main river bed (Castella et al., 1984; Van den Brink et al., 1996).

Whereas the lack of rheobionts in the fauna of standing water bodies of the Krapiel river valley may be explained also by the lack of small river tributaries and, therefore, lack of habitats with rapid strong current, the minor contribution of rheophiles and stagnobionts "a", particularly in oxbows, is a 


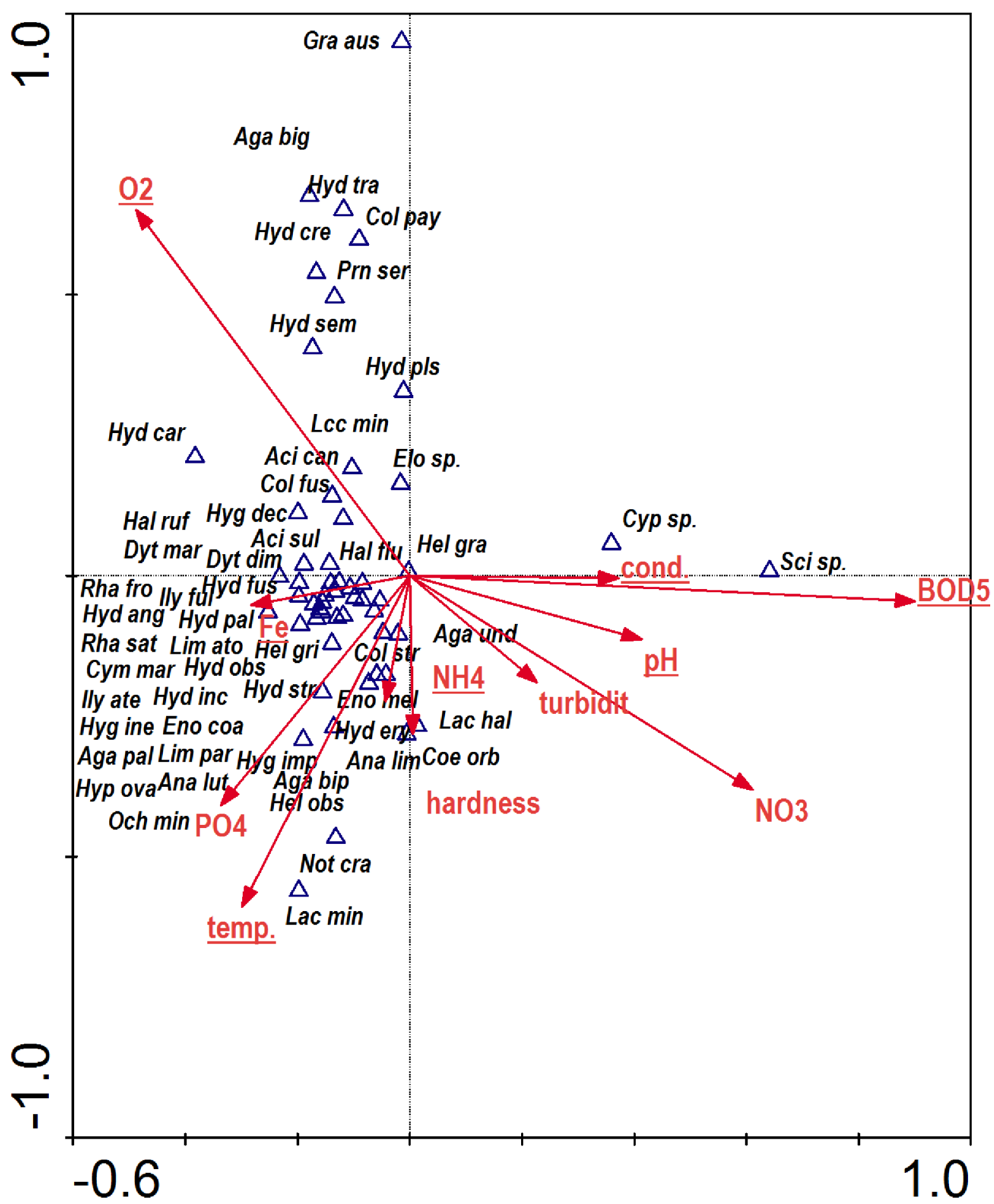

Fig. 10. The CCA ordination plot of occurrence of water beetles in relation to the physcial and chemical parameters of water along the first and second CCA axis. Full species names are given in Table 3.

consequence of lack of circulation of river water therein during floods which contributed to their eutrophication. The eutrophication results in the modification of the fauna composition towards the domination of stagnobionts " $b$ " in the fauna, as observed in the valley of Narew (Biesiadka and Pakulnicka, 2004a). At the same time, the fauna of Krapiel oxbows did not include Porhydrus lineatus and Hygrotus versicolor, whereas Colymbetes striatus was scarce. Accord- ing to Biesiadka and Pakulnicka (2004a) these species are strictly related to clean oxbow wasters which, being regularly circulated by the river water, have limited trophic development, thus maintaining their ecological stability.

The beetles of the discussed water body types among which stagnobionts are prevalent, are characterized by not only broad scope of ecological tolerance but developed ability to fly which is of importance for development of fauna relationships 
in the river valley, especially with limited hydrological contact of studied water bodies. For the organisms dispersing by air, the land environment and particularly the landscape structure and manner of its use may be of great importance (e.g. Richards and Host, 1994; Richards et al., 1996; Pither and Taylor, 1998; Robinson et al., 2002). Some authors also point to the distance between the water body and the main river bed (Sanderson et al., 2005).

Topographic features such as compact development or dense forest patches may constitute barriers obstructing the dispersion of beetles. It follows from the data discussed in this paper that the dependencies between landscape factors, such as $\mathrm{Cr}$ of civil structures or the area of individual patches, i.e. forests, marshlands or agricultural land, and the fauna composition of water beetle groups were average and generally negative for the majority of species. This observation allows us to conclude the mentioned landscape features have a rather limiting impact on the researched beetle populations. Positive relationships between landscape factors and species were found only in 12 species and these are weak (present in $A$. sulcatus, Scirtes spp., H. striola, H. obscurus, H. angustatus, I. ater, $H$. fluviatilis) or average correlations at most (e.g. in $H$. caraboides).

Also the other analyzed characteristics, including the size and shape of patches, had little influence on the water beetle populations, a fact reflected in the positive or negative correlations being either average or weak. An exception to this is posed by C. paykulli, P. serricornis and A. biguttatus which show strong correlations with the number of forest patches within the cachment. These correlations are justified particularly with regard to one species which inhabits the springs located often in forest surroundings. The indicated species also showed strong correlations with density of forests and distance between a habitat and the flowing water body which, undoubtedly, should be referred to considerable distance between river springs and actual flowing water body (river).

Due to close proximity of the analyzed water bodies and the River Krąpiel, as well as active flights of beetles between these environments, the compact characteristics of the river has major influence on the fauna. The analysis of river bed structure impact on the arrangement of water beetles in the river valley indicates that almost 30 species show a positive relationship with vegetation overgrowth and organic matter. This group shows major ecological diversity - these are mainly stagnobionts "b" which are accompanied also by stagnobionts "a", rheophiles and crenophiles, whereas $L$. minutus, A. bipustulatus and A. biguttatus seem to show the strongest relationship. The remaining species show positive relationship with the size of bed deposits and mineral matter. The group includes large contribution of stagnobionts "a" (species from genera Helophorus, Hydroporus, Laccobius) and rheophiles (H. fluviatilis and A. paludosus). The high degree of dependency of beetle fauna and water body overgrowth by macrophytes is highlighted also by Sanderson et al. (2005), Pakulnicka (2008), Pakulnicka and Nowakowski (2012) and Pakulnicka et al. (2015a,b).

The character of fauna relationships in individual water bodies is likely to be influenced by the physical and chemical properties of water (e.g. Marchese and Ezcurra de Drago, 1992; Sanderson et al., 2005; Costea et al., 2013; Pakulnicka et al., 2015b). It follows from our data that among the analyzed physical and chemical factors of water in the examined water bodies, statistically significant $(p<0.05)$ impact on the species composition of beetle fauna is demonstrated by: temperature, saturation $\left(\mathrm{O}_{2}\right)$, conductivity, $\mathrm{BOD}_{5}, \mathrm{pH}$ and $\mathrm{NH}_{4}$. These dependencies seem to be of greater importance for many species which is confirmed by stronger correlation. Very large group of species shows positive correlations with the temperature and $\mathrm{O}_{2}$ and negative correlations with $\mathrm{pH}$ and BOD. These are mainly stagnobionts " $b$ " accompanied by numerous stagnobionts "a" related to less eutrophicated waters, including acidic waters. In turn, the positive correlations with $\mathrm{O}_{2}$ and negative correlations with temperature is shown by 17 species among which very strong correlation is shown by a crenophile $-A$. biguttatus which prefers cold and well oxygenated, clean spring waters (Pakulnicka, 1999; Pakulnicka et al., 2016).

The studies of the Krapiel river valley allowed to obtain a perspective of water beetle fauna that is different from the one expected on the basis of topography and, especially, close proximity of water environments present here. High diversity of water bodies in the Krapiel river valley is conducive to high local species richness which is confirmed by the results of studies conducted in other areas of this kind (e.g. Stanley et al., 1997; Wissinger, 1999; Junk, 2000; Tockner et al., 2000; Robinson et al., 2002; Costea et al., 2013). However, the fact that the beetle fauna is dominated by stagnobionts and the fact that a very small contribution of species related to moving water bodies, both in individual water body types as well as for the entire valley, mean that there is no symmetry in the directions of beetle migration: migration from valley water bodies to the river is much higher than migration from the river back to such water bodies. This observation is also confirmed in the results of studies on Hydrachnidae (Zawal et al., 2015). This may be convincingly explained when considering the smaller than expected hydrological contact between the water bodies resulting from the valley's topography, and only rare flooding which does not reach many of the water bodies, especially those located away from the main riverbed (Marchese and Ezcurra de Drago, 1992; Smock, 1994; Ward et al., 2002; Biesiadka and Pakulnicka, 2004a; Pakulnicka and Nowakowski, 2012). Decreased hydrological contact between the valley's individual ecosystems and the main riverbed typically results in modification of their fauna (Castella et al., 1984; Van den Brink et al., 1996; Biesiadka and Pakulnicka, 2004a; Costea et al., 2013). On one hand, this contributes to their eutrophication (unfortunately also of oxbows) as well as their individualism. On the other hand, the lack of flooding reduces the drift of organisms from hatching habitats, which, in turn, reduces the river's species richness (Marchese and Ezcurra de Drago, 1992; Biesiadka and Pakulnicka, 2004a; Pakulnicka and Nowakowski, 2012).

An additional factor limiting the migration of beetles between the water bodies of the Krapiel river may involve certain landscape features of the catchments, which form topographical obstacles, mainly numerous and dense forest areas. All this means that every water body maintains a highly individual character and thus the entire system is less integrated in terms of fauna, as compared to other rivers with a distinct floodplain. The character of the fauna in individual types of water bodies also seems to be affected by internal 
environmental factors, particularly the degree of overgrowth by macrophytes, type of bottom, type of mineral and organic matter as well as the water's physical parameters such as saturation, $\mathrm{pH}$, temperature and $\mathrm{BOD}_{5}$, which reflect the degree of eutrophication of water bodies. This is evident when considering the high correlations between the mentioned factors and many beetle species, as demonstrated by the authors of this paper. However, for many others for which weak or average correlations are shown, these factors remain insignificant. This could point to the conclusion that the cooccurrence of certain species does indeed sometimes comply with niche theories according to which the most important are beneficial environmental conditions, while at other times species co-occurrence remains accidental, in line with the neutral theory (Pakulnicka et al., 2013).

The standing water bodies in river valleys are of crucial importance in the protection of biological diversity. They are not only a place inhabited by numerous and diversified fauna, but most of all they ensure survival for periodic colonizing species from habitats in which living conditions are deteriorating. Thus, they often become the place of occurrence of rare species. In this context, the following items demonstrated in our studies may be of further significance: (1) Species recorded in Poland rarely (Agabus neglectus, Graphoderus austriacus, H. incognitus, Helophorus pumilio, Cercyon sternalis) and very rarely (Spercheus emarginatus, Enochrus halophilus, Hydraena pulchella) (Petryszak, 2004; Przewoźny, 2004); (2) A species at high risk of extinction in Poland (conservation status $\mathrm{EN}=$ Endangered) (Hydroporus morio) (Pawłowski et al., 2002); (3) Hydrophilus sp. larvae, pointing to the presence of one of the two species of this genus which occur in Poland - both are subject to legal protection and registered with the Polish Red List of Beetles (Pawłowski et al., 2002).

Acknowledgements. Financial support was provided by the Ministry of Science and Higher Education, No. N N305 222537. We would like to thank Professor Rafał Gosik for his kind help in identifying beetles from the Curculionidae family.

\section{References}

Bańkowska A, Kłosowska M, Stryjecki R,Zawal A. 2015. New and rare water mite (Hydrachnidia) species in Polish fauna found in the Krapiel River and valley water bodies in Ińskie Lake District. Acta Biol 22: 15-37.

Bilton DT. 1994. The flight apparatus and flying ability of Hydroporus glabriusculus (Coleoptera, Dytiscidae), with a brief review of structural modifications in flightless beetles. Entomol Tidskr 115: 23-32.

Biesiadka E. 1974. Hydracarina of the river Raba and some of its tributaries. Acta Hydrob 16: 31-50.

Biesiadka E, Kurzątkowska A. 2003. Water Bugs (Heteroptera) of Nieman River, some of its tributaries and riverine reservoirs. Fragm Faun 46: 131-149.

Biesiadka E, Pakulnicka J. 2004a. Water beetles (Coleoptera) in Łomz yński Landscape Park of Valley of Narew River. Parki Nar Rez Przyr 23: 427-447 [in Polish].

Biesiadka E, Pakulnicka J. 2004b. Habitat distribution of water beetles (Coleoptera) in the middle reaches of the Neman river. Latvijas Entomologs 41: 9-18.
Biesiadka E, Cichocka M, Moroz M. 2004. Water mites (Hydrachnidia) from the Neman River, some of its tributaries and riverine reservoirs. Fragm Faun 7: 143-164.

Bray J, Curtis JT. 1957. An ordination of the upland forest communities of southern Wisconsin. Ecol Monogr 27: 325349 .

Buczyński P. 2007. Dragonflies (Odonata) of the valley of the River Bug between Gołębie and Włodawa. Nowy Pam Fizjogr 5: 3-26 [in Polish].

Castella E, Amoros C. 1988. Freshwater macroinvertebrates as functional describers of the dynamics of the former river beds. Verh Internat Verein Theor Angew Limnol 23: 1299-1305.

Castella E, Richardot-Coulet M, Roux C, Richoux P. 1984. Macroinvertebrates as "describers" of morphological and hydrological types of aquatic ecosystems abandoned by the Rhone River. Hydrobiologia 119: 219-225.

Castella E, Richardot-Coulet M, Roux C, Richoux P. 1991. Aquatic macroinvertebrate assemblages of two contrasting floodplains: the Rhône and Ain rivers, France. Regul Rivers Res Manage 6: 289-300.

Costea G, Cojocaru I, Pusch M. 2013. The Aquatic Beetles (Insecta: Coleoptera) assemblages in the Lower Prut Floodplain Natural Park (Romania). Natura Montenegr 12: 719-736.

Czachorowski S. 2004. The Last Natural Eastern River? Caddisflies (Trichoptera) of the Neman River. Latvijas Entomologs 41: 44-51.

Czachorowski S, Lewandowski K, Wasilewska A. 1993. The importance of aquatic insects for landscape integration in the catchment area of the river Gizela (Masurian Lake District, northeastern Poland). Natura Montenegr 35: 49-64.

Dąbkowski P, Buczyński P, Zawal A, et al. 2016. The impact of dredging of a small lowland river on water beetle fauna (Coleoptera). J Limnol 75 (3): 472-487.

Delettre YR, Morvan N. 2000. Dispersal of adult aquatic Chironomidae (Diptera) in agricultural landscapes. Freshwater Biol 44: 399-411.

Delettre YR, Tréhen P, Grootaert P. 1992. Space heterogeneity, space use and short-rangedispersal in Diptera: a case study. Landsc Ecol 6: $175-181$.

Galic N, Hengeveld GM, van den Brink PJ, et al. 2013. Persistence of aquatic insects across managed landscapes: effects of landscape permeability on re-colonization and population recovery. PLoS ONE 8: e54584.

Giora M. 2014. Habitats. In: Donald Y, ed. Ecology, systematics, and the natural history of predaceous diving beetles (Coleoptera: Dytiscidae). Netherlands: Springer, pp. 307-363.

Junk WJ. 2000. Mechanisms of development and maintenance of biodiversity in neotropical floodplains. In: Gopal B, Junk WJ, Davis JA, eds. Biodiversity in wetlands: assessment, function and conservation. Leiden: Backhuys Publishers, pp. 119-139.

Jurkiewicz-Karnkowska E. 2006. Communities of aquatic molluscs in floodplain water bodies of lowland river (Bug River, East Poland). Pol J Ecol 54: 253-266.

Kajak Z. 1959. The role of water rise in raising up and drifting of benthic fauna in ecosystems connected with rivers. Pol J Ecol 5: 47-53 [in Polish].

Koch K. 1989. Die Käfer Mitteleuropas, Band E1. Ökologie: Carabidae-Micropeplidae. Krefeld: Goecke \& Evers.

Kowalik W, Zawal A, Buczyńska E. 2014. Water mites (Acari, Hydrachnidia) of the River Szum and Stream Krupiec in the Roztocze region. Acta Biol 21: 75-89.

Lundkvist E, Landin J, Milberg P. 2001. Diving beetle (Dytiscidae) assemblages along environmental gradients in an agricultural landscape in Southeastern Sweden. Wetlands 21: 48-58. 
Lundkvist E, Landin J, Karlsson F. 2002. Dispersing diving beetles (Dytiscidae) in agricultural and urban landscapes in south-eastern Sweden. Ann Zool Fenn 39: 109-123.

Marchese M, Ezcurra de Drago I. 1992. Benthos of the lotic environments in the middle Paraná River system: transverse zonation. Hydrobiologia 237: 1-13.

McAleece N, Lambshead PJD, Paterson GLJ. 1997. Biodiversity Pro. London: The Natural History Museum.

Mielewczyk S. 2003. Wiosenny stan entomofauny (Odonata, Heteroptera, Coleoptera) w Rzece Warcie i zbiornikach przyrzecznych w Nadwarciańskim Parku Krajobrazowym. $R$ Nauk Pol Tow Ochr Przyr Salamandra 7: 87-99.

Moroz M, Pakulnicka J, Lukaszuk A. 2004. Fauna of the bugs (Heteroptera) and beetles (Coleoptera) in the watercourses of the Berezina River basin in the Berezinski Biosphere Reserve. Parki Nar Rez Przyr 23: 247-259 [in Polish].

Obolewski K, Glińska-Lewczuk K, Kobus S. 2009. Effect of hydrological connectivity on the molluscan community structure in oxbow lakes of the Łyna river. Oceanol Hydrobiol St 37: $75-88$.

Oertli B, Joye DA, Castella E, Juge R, Cambin D, Lachavanne JB. 2002. Does size matter? The relationship between pond area and biodiversity. Biol Conserv 104: 59-70.

Pakulnicka J. 1999. The state of research on aquatic beetles (Coleoptera Aquatica) of springs in Poland. In: Biesiadka E, Czachorowski S, eds. Springs in Poland - state of research, monitoring and protection. Olsztyn: Wydawnictwo Wyzszej Szkoły Pedagogicznej w Olsztynie, pp. 149-155 [in Polish].

Pakulnicka J. 2008. The formation of water beetle fauna in anthropogenic water bodies. Oceanol Hydrobiol St 37: 1-12.

Pakulnicka J., Nowakowski J.J. 2012. The effect of hydrological connectivity on water beetles fauna in water bodies within the floodplain of a lowland river (Neman river, Belarus). Oceanol Hydrobiol St 41: 7-17.

Pakulnicka J, Górski A, Bielecki A, Buczyński P, Tończyk G, Cichocka M. 2013. Relationships within aquatic beetle (Coleoptera) communities in the light of ecological theories. Fundam Appl Limnol 183: 249-258.

Pakulnicka J, Buczyńska E, Buczyński P, et al. 2015a. Are beetles good indicators of insect diversity in freshwater lakes? Oceanol Hydrobiol St 44: 487-499.

Pakulnicka J, Górski A, Bielecki A. 2015b. Environmental factors associated with biodiversity and the occurrence of rare, threatened, thermophilous species of aquatic beetles in the anthropogenic ponds of the Masurian Lake District. Biodivers Conserv 24: 429-445.

Pakulnicka J, Buczyński P, Dąbkowski P, et al. 2016. Aquatic beetles (Coleoptera) in springs of a small lowland river: habitat factors vs landscape factors. Knowl Manag Aquat Ecosyst 417: 29.

Pawłowski J, Kubisz D, Mazur M. 2002. Coleoptera beetles. In: Głowaciński Z, ed. Red list of threatened animals in Poland. Kraków: Wydawnictwo Instytutu Ochrony Przyrody Polskiej Akademii Nauk, pp. 88-110 [in Polish].

Persson Vinnersten TZ, Lundström JO, Petersson E, Landin J. 2009. Diving beetle assemblages of flooded wetlands in relation to time, wetland type and Bti-based mosquito control. Hydrobiologia 635: 189-203.

Petryszak B. 2004. Adephaga. In: Bogdanowicz W, Chudzicka E, Filipiuk I, Skibińska E, eds. Fauna of Poland, characteristics and checklist of species. Warszawa: Muzeum i Instytut Zoologii PAN, pp. 28-44.

Pither J, Taylor PD. 1998. An experimental assessment of landscape connectivity. Oikos 83, 166-174.
Płaska W, Kurzątkowska A, Stępień E, et al. 2016. The effect of dredging of a small lowland river (Krapiel - NW Poland) on aquatic Heteroptera. Ann Zool Fenn 53: 139-153.

Przewoźny M. 2004. Hydrophyloidea. In: Bogdanowicz W, Chudzicka E, Filipiuk I, Skibińska E, eds. Fauna of Poland, vharacteristics and checklist of species. Warszawa: Muzeum i Instytut Zoologii PAN, pp. 149-151.

Przewoźny M, Buczyński P, Mielewczyk S. 2006. Aquatic beetles (Coleoptera: Adephaga, Hydrophiloidea, Byrrhoidea) of the valley of the River Bug in the Lublin District (South-Eastern Poland). Nowy Pam Fizjogr 4: 23-54 [in Polish].

Reckendorfer W, Baranyi C, Funk A, Schiemer F. 2006. Floodplain restoration by reinforcing hydrological connectivity: expected effects on aquatic mollusc communities. $J$ Appl Ecol 43: 474-484.

Richards C, Host G. 1994. Examining land use influences on stream habitats and macroinvertebrates: a GIS approach. Water Resour Bull 30: 729-738.

Richards C, Johnson LB, Host G. 1996. Landscape-scale influences on stream habitats and biota. Can J Fish Aquat Sci 53: 295-311.

Robinson CT, Tockner K, Ward V. 2002. The fauna of dynamic riverine landscapes. Freshwater Biol 47: 661-677.

Sanderson RA, Eyre MD, Rushton SP. 2005. Distribution of selected macroinvertebrates in a mosaic of temporary and permanent freshwater ponds as explained by autologistic models. Ecography 28: 355-362.

Smock LA. 1994. Movements of invertebrates between stream channels and forested floodplains. J North Am Benthological Soc 13: $524-531$.

Sokal RR, Sneath PHA. 1995. Biometry. San Francisco: W. H. Freeman and Co.

Stanford JA,Ward JV, Liss WJ, et al. 1996. A general protocol for restoration of regulated rivers. Regul Rivers Res Manage 12: 391-413.

Stanley EH, Fisher SG, Grimm NB. 1997. Ecosystem expansion and contraction in streams. Bioscience 47: 427-436.

Stępień E, Zawal A, Buczyński P, Buczyńska E. 2015. Changes in the vegetation of small lowland river valley (Krapiel, NW Poland) after dredging. Acta Biol 22: 168-196.

Stryjecki R, Kowalczyk-Pecka D. 2013. A faunistic and ecological characterization of the water mites (Acari: Hydrachnidia) of the highly anthropologically transformed Mietiulka river in Polesie. National Park Environ 24: 11-15.

Szlauer-Łukaszewska A, Zawal A. 2014. The impact of river dredging on ostracod assemblages in the Krapiel River (NW Poland). A faunistic and ecological characterization of the water mites (Acari: Hydrachnidia) of the highly anthropologically transformed Mietiulka river in Polesie National Park. Fundam Appl Limnol 185: 295-305.

ter Braak CJF. 1986. Canonical correspondence analysis: a new eigenvector technique for ultivariate direct gradient analysis. Ecology, 67: 1167-1179.

ter Braak CJF, Verdonschot PFM. 1995. Canonical correspondence analysis and related multivariate methods in aquatic ecology. Aquat Sci 57: 255-289.

Tockner K, Malard F, Ward JV. 2000. An extension of the flood pulse concept. Hydrol Process 14: 2861-2883.

Van den Brink FWB, Van der Velde G. Buijse AD, Klink AG. 1996. Biodiversity in the lower Rhine and Meuse river-floodplains: its significance for ecological river management. Neth J Aquat Ecol 30: $129-149$.

Ward JV. 1998. Riverine landscapes: biodiversity patterns, disturbance regimes, and aquatic conservation. Biol Cons 83: 269-278. 
Ward JV, Tockner K, Schiemer F. 1999. Biodiversity of floodplain river ecosystems: ecotones and connectivity. Regul Rivers Res Manage 15: 125-139.

Ward JV, Tockner K, Arscott DB, Claret C. 2002. Riverine landscape diversity. Freshw Biol 47: 517-539.

Winfield Fairchild G, Faulds AM, Matta JF. 2000. Beetle assemblages in ponds: effects of habitat and site age. Freshw Biol 44: 523-534.

Wissinger SA. 1999. Ecology of wetland invertebrates: synthesis and applications for conservation and management. In: Batzer DP, Rader RB, Wissinger SA. eds. Invertebrates in freshwater wetlands of North America, ecology and management. New York: John Wiley and Sons, pp. 1043-1086

Zawal A, Kowalik W. 2013. Water Mites of the Biała Łada nd Czarna Łada Rivers in the Lublin Region. Annales Universitatis Mariae Curie-Sktodowska, Sectio C 93, pp. 117-125.

Zawal A, Stępień E, Szlauer-Łukaszewska A, et al. 2015. The influence of a lowland river dredging (the Krapiel in NW Poland) on water mite fauna (Acari: Hydrachnidia). Fundam Appl Limnol 186: $217-232$.

Zawal A, Czachorowski S, Stępień E, et al. 2016a. Early post-dredging recolonization of caddisflies (Insecta: Trichoptera) in a small lowland river (NW Poland). Limnology 17: 71-85.

Zawal A, Lewin I, Stępień E, et al. 2016b. The influence of landscape structure within buffer zones, catchment land use and instream environmental variables on mollusc communities in a mediumsized lowland river. Ecol Res 31 (6): 853-867.

Zawal A, Stryjecki R, Stępień E, et al. 2016c. Water mites (Acari, Hydrachnidia) of water bodies of the Krapiel River valley interactions in the spatial arrangement of a river valley. Limnology 17 (3): 247-261.

Zawal A, Sulikowska-Drozd A, Stępień E, Szlauer-Łukaszewska A, Jankowiak Ł. 2016d. Regeneration of the molluscan fauna of a small lowland river after dredging. Fundam Appl Limnol 187 (4): 281-293.

Cite this article as: Pakulnicka J, Buczyński P, Dąbkowski P, Buczyńska E, Stępień E, Szlauer-Łukaszewska A, Zawal A. 2016. Development of fauna of water beetles (Coleoptera) in waters bodies of a river valley - habitat factors, landscape and geomorphology. Knowl. Manag. Aquat. Ecosyst., 417, 40. 